\title{
ANATOMY OF A STRIKE-SLIP FAULT CONTROLLED SEDIMENTARY BASIN, PERMIAN OF THE SOUTHERN PYRENEES, SPAIN
}

\author{
ARIE SPEKSNIJDER * \\ Department of Structural Geology, State University Utrecht, P.O. Box 80021, 3508 TA Utrecht (The \\ Netherlands)
}

(Received October 15, 1984; revised and accepted November 5, 1984)

\begin{abstract}
Speksnijder, A., 1985. Anatomy of a strike-slip fault controlled sedimentary basin, Permian of the southern Pyrenees, Spain. Sediment. Geol., 44: 179-223.
\end{abstract}

This study is mainly concerned with a $55 \mathrm{~km}$ long, east-west oriented strike section through a thick succession of dominantly clastic post-Variscan deposits in the Spanish Pyrenees south of Andorra. A subdivision into three formations can be made: two formations of Stephanian age, composed of volcanic rocks and fluviatile sediments respectively, and one of probable Permian age which has been studied in detail and is entirely composed of terrestrial redbeds. These three formations are characterised by large variations in thickness along strike. Thicknesses vary from 0 to $800 \mathrm{~m}$ in the volcanics, from 0 to $300 \mathrm{~m}$ in the Stephanian fluviatile sediments and from 0 to $1500 \mathrm{~m}$ in the Permian redbeds. The geometry of the sedimentary bodies in all three formations suggests deposition in an east-west oriented graben-like depression, a conclusion which is confirmed by detailed sedimentological analysis of the Permian rocks.

The vertical succession of Permian sediments can be subdivided in six major basinfill sequences which unconformably overlie each other. Internally the basinfill sequences are built up of one or more coarsening-upward/fining-upward cycles. The genesis of these cycles is directly related to dip-slip movement along the basin boundary faults, whereas the unconformities between the basinfill sequences indicate that periods of basin subsidence and sedimentation were followed by periods of deformation and erosion. These changes in tectonic regime as reflected in the sedimentary sequences are interpreted to indicate alternating phases of transtension and transpression in a strike-slip zone. Other sedimentological observations substantiate this interpretation. The basin depocentre shifted in space and time, which resulted in the observed large variations in sediment thickness along strike, together with eastward paleocurrent directions along the basin axis.

Transtension was accompanied by outpouring of andesitic lavas and drape folding on a large scale. During transpressional phases normal faults changed character to reverse faults while folding, uplift and subsequent erosion resulted in the formation of intrabasinal unconformities. Alternation of transpressive and transtensive conditions should be the result of movement along non-planar fault surfaces in a major strike-slip zone. A separate structural study of the Variscan basement of the studied basin revealed the

* Present address: Koninklijke/Shell Exploratie en Produktie Laboratorium, Volmerlaan 6, 2288 GD Rijswijk, The Netherlands. 


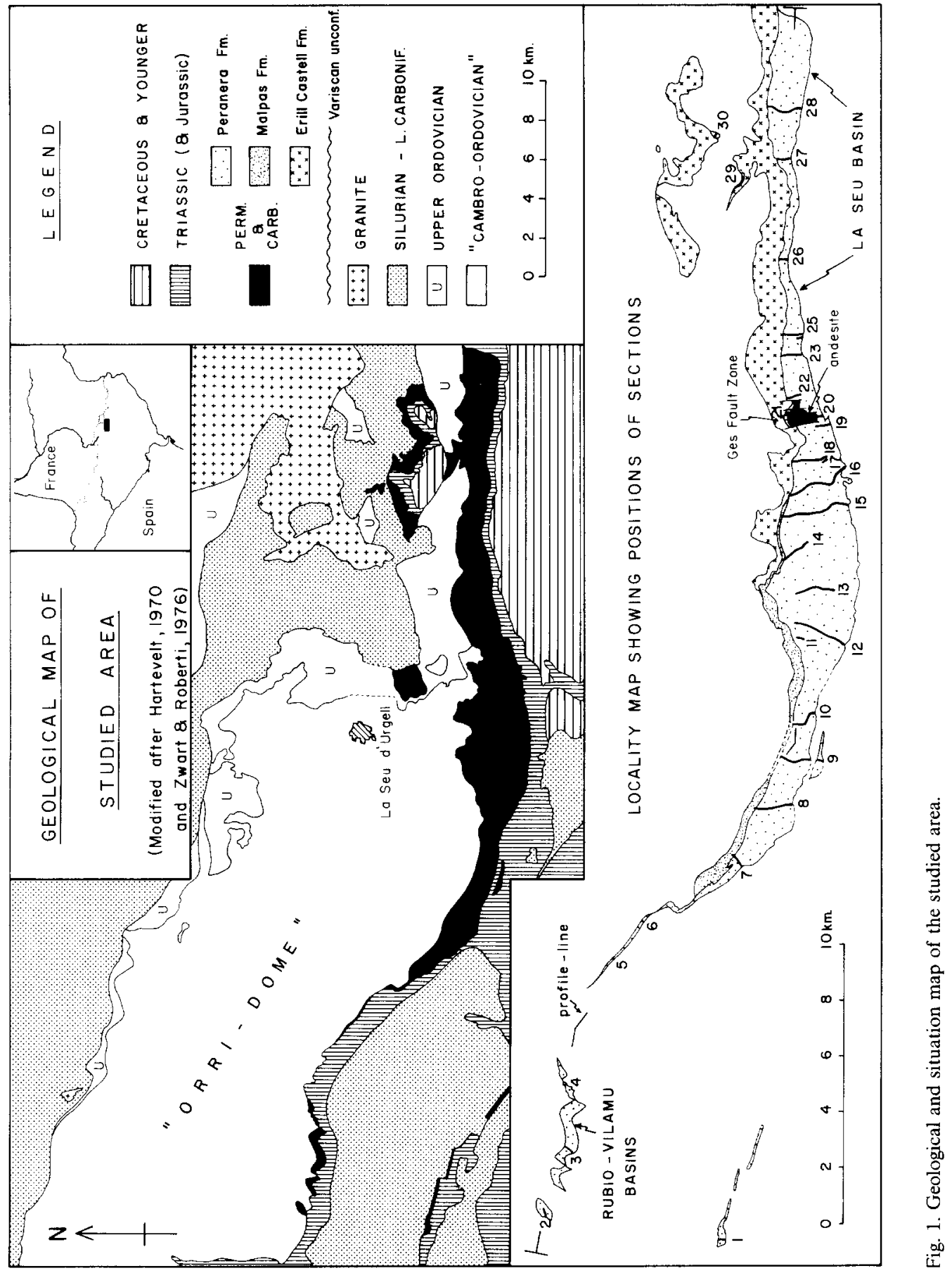


existence of a dextral simple-shear deformation generation of probable Stephano-Permian age. Simple shear in the basement on the one hand, and brittle superficial strike-slip faulting involving transtension and transpression on the other, are considered to be expressions of the same regional stress field at different levels in the Earth's crust.

\section{INTRODUCTION}

This paper forms part of a series in which the relationship between structural and depositional history of a number of dominantly strike-slip sedimentary basins is investigated using both structural and sedimentological data.

The present article mainly deals with a detailed sedimentological description and interpretation of a sequence of terrestrial redbeds of probable Permian age known as the Peranera Formation (Nagtegaal, 1969), which accumulated in a number of elongated fault-bounded basins in the Spanish southern Pyrenees. In addition, it analyses the geometry and evolution of these basins, partly with the aid of structural data from the underlying basement.

Figure 1 shows the geographical distribution of the studied basins: to the east the large La Seu basin, called after the town of La Seu d'Urgell, some $5 \mathrm{~km}$ north of the present-day outcrop area of the basin. The associated small Rubio-Vilamu basins to the west have been named after the villages of the same names.

Careful sedimentological study involving interpretation of depositional environment for the various lithotypes recognized, the grouping of these lithotypes into facies, facies associations and sequences, and finally the study of paleocurrent data turned out to be a powerful tool in the analysis of the structural organisation and the evolution of the sedimentary basins where structural analysis alone would have been inadequate.

\section{Geological setting and structural geology of the basement}

The La Seu and Rubio-Vilamu basins crop out with dominant east-west strike over a length of $55 \mathrm{~km}$ along the southern border of the so-called Axial Zone of the Pyrenees. The Axial Zone consists of rocks folded, metamorphosed and intruded during the Variscan orogeny (Zwart, 1979), while the basins contain unmetamorphosed sediments of Westphalian D and younger Paleozoic age which unconformably overlie the Variscan basement. The stratigraphy of these basinfills, which is summarized in Fig. 2, has been set up by Mey (1968), Mey et al. (1968) and Nagtegaal (1969). The latter author carried out a detailed study of similar postVariscan rocks in an area to the west of the La Seu basin.

The redbeds of the Peranera Formation form the main subject of the present paper. Although their precise age is not known, they are generally regarded to be of Permian age, as they occur between sediments of proven Stephanian and Lower Triassic age (Hartevelt, 1970). 


\begin{tabular}{|c|c|c|c|c|}
\hline & & redbeds & "Bunter" & L. Triassic \\
\hline $\begin{array}{l}\text { É } \\
0 \\
O \\
\frac{D}{1} \\
1 \\
0\end{array}$ & $=--$ & $\begin{array}{l}\text { redbeds; conglomerate, } \\
\text { sandstone ond silt }\end{array}$ & $\begin{array}{l}\text { Peranera } \\
\text { Formation }\end{array}$ & Permian \\
\hline $\begin{array}{l}8 \\
8 \\
m \\
1 \\
\end{array}$ & $\frac{1+1}{6+1}$ & $\begin{array}{l}\text { conglomerote, sandstone, } \\
\text { silt, some coallayers }\end{array}$ & $\begin{array}{l}\text { Malpas } \\
\text { Formation }\end{array}$ & \\
\hline $\begin{array}{l}E \\
\\
0 \\
0 \\
\infty \\
1 \\
0\end{array}$ & 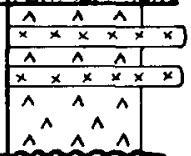 & $\begin{array}{l}\text { tuff and } \\
\text { basaltic andesite }\end{array}$ & $\begin{array}{l}\text { Erill } \\
\text { Castell } \\
\text { Formation }\end{array}$ & Stephanion \\
\hline & & $\begin{array}{l}\text { folded and } \\
\text { cleaved slate a ssts. }\end{array}$ & \multicolumn{2}{|c|}{ Variscan basement } \\
\hline
\end{tabular}

Fig. 2. Generalized stratigraphical section of post-Variscan rocks in the south-central Pyrenees. No scale implied. Thicknesses refer to present study area.

As a result of strong Tertiary uplift of the Axial Zone, the beds of the Peranera Formation, as well as the Variscan unconformity plane, now dip approximately $45^{\circ}$ towards the south. Consequently, the directly underlying Variscan rocks must also have been influenced by this tilting. This implies that Paleozoic rocks now cropping out just north of the inclined Variscan unconformity, once formed part of the basement more or less underlying the La Seu and Rubio-Vilamu basins. Therefore, a structural study of the Variscan basement north of the present outcrop of the Peranera Formation will provide useful information on the deformation of the rocks that once lay below the La Seu basin, and may thus help clarify the structural setting of the basin.

A structural analysis of the so-called Orri-dome (Hartevelt, 1970; see Fig. 1) revealed the occurrence of five or six separate Variscan deformation generations, one of post-Variscan Paleozoic (probably Stephano-Permian) age and at least two of Alpine age (Speksnijder, unpublished data). The Stephano-Permian deformation is thought to have been of primary importance to the development of the La Seu basin. It was of the simple shear type and caused dextral east-west shear movements along various anisotropy planes of Variscan age such as cleavages, steep faults and thrusts. Dextral east-west simple shear in the basement and development of an east-west aligned strike-slip basin at the surface are proposed to be different expressions of the same regional stress field at different levels in the crust. 


\section{Previous work}

Apart from Nagtegaal's (1969) work west of the present study area, the Peranera Formation was briefly described by Hartevelt (1970), who made the first detailed map of the outcrop area of the La Seu basin. The map by Zwart and Roberti (1976) includes the Rubio-Vilamu basins, while Hartevelt and Roger (1968) present a brief description of one of these basins. Sopeña et al. (1977) give a review of the occurrence of Permian rocks in the Spanish Pyrenees. References to earlier work are given by the authors mentioned above. More recently, Gisbert (1981) published an abstract of his thesis covering the sedimentology of Stephanian, Permian and Lower Triassic rocks in the same area with emphasis on diagenesis and paleoclimatology. His conclusions regarding the environment of deposition of the sedimentary sequence fully agree with mine.

Bixel and Lucas (1983) describe the magmatism, tectonics and sedimentation in Stephano-Permian basins in the western Pyrenees. These authors attribute the opening of the sedimentary basins to E-W directed "late Hercynian transcurrent shearing" which partly reactivated older Variscan structures. The concept of basin formation by reactivation of basement structures in the western Pyrenees was already forwarded by Soula et al. (1979).

\section{Methods of study}

In order to analyse the geometry and sedimentary history of the La Seu and Rubio-Vilamu basins, a great part of this study was taken up by fieldwork. Some 30 sections were measured on a 1:500 scale, in total representing more than $10 \mathrm{~km}$ of (stratigraphic) sediment thickness (Fig. 1).

Special attention was paid to sedimentary structures and the paleocurrent directions they reveal, although in most sections sedimentary structures were hard to recognize due to poor outcrop conditions. The properties of some conglomerate beds, including maximum pebble size, sorting, bed thickness/maximum pebble size ratio and pebble composition were determined in order to throw some light upon mode of transportation and deposition. Maximum pebble size was defined as the mean of the longest axes of the three largest pebbles in a conglomerate bed that occur in a zone approximately $1-5 \mathrm{~m}$ wide on both sides of the section line (Bluck, 1967).

Correlations between adjacent sections are based on similarities of distribution of very coarse- and very fine-grained intervals, fining upward (FU) and coarsening upward $(\mathrm{CU})$ patterns, pebble composition, study of aerial photographs and direct tracing of beds in the field.

\section{SEDIMENTARY FACIES}

In the Permian rocks of the La Seu and the Rubio-Vilamu basins the following sedimentary facies have been distinguished: (1) breccia facies; (2) conglomerate 
facies; (3) pebbly sandstone and coarse cross-bedded sandstone facies; (4) finegrained sandstone facies; and (5) silt and clay facies.

As will be shown in the next section, these facies can be grouped into three facies associations.

\section{Breccia facies}

\section{Description}

The breccia facies only occurs in the lowest levels of the Rubio-Vilamu basins (sections 2-5) and in the top of section 9 (see Fig. 1 for positions of sections). In the

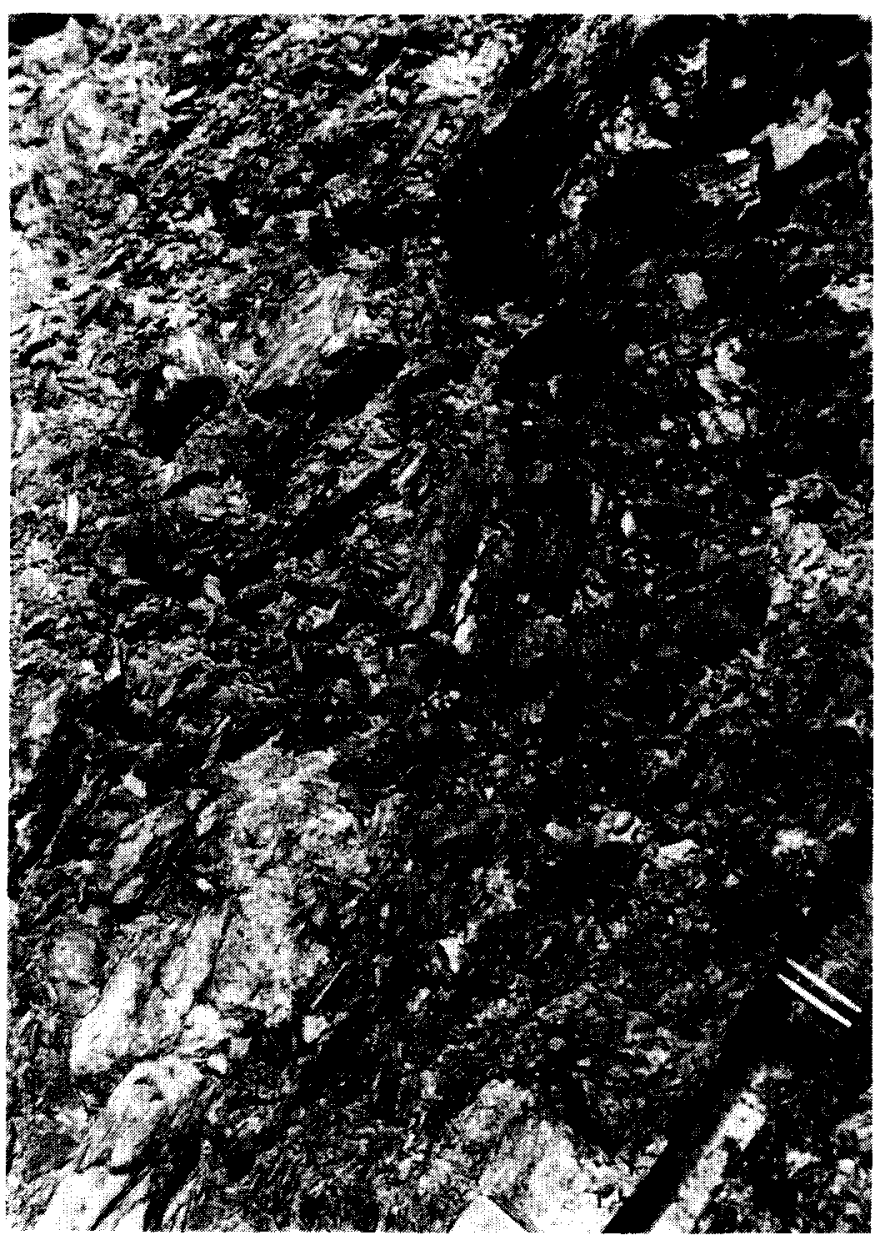

Fig. 3. Breccia at the base of section 3, just above the Variscan unconformity plane. For position see Fig. 10. The hammershaft lies approximately parallel to the unconformity plane; the sequence becomes younger towards the left. 
former case they are composed of angular to very angular cobbles and pebbles, and are without exception derived from the Ordovician slates and sandstones on which they rest unconformably. A profile typical of the transition zone from Variscan to post-Variscan rocks shows from bottom to top: Unaltered folded and cleaved sandstones and slates; weathered to strongly weathered rocks, often with faint pink staining; loose but in-situ fragments, often dragged apart, with some infill of red sandstone and mud between them; and, finally, breccia consisting of red-stained coarse debris in a red sandstone and/or silt matrix (Fig. 3).

Higher in the breccia units the fragments usually float in the matrix which largely consists of silt. The units show no internal structure, pebbles have no preferred orientation and are very badly sorted. Complete sequences show, nevertheless, marked fining-upward tendencies. Breccia units are separated from each other by thin layers of silt, pebbly siltstone or (pebbly) fine sandstone.

Although individual breccia units have maximum thicknesses of 10-12 m, they occur to a height of $30 \mathrm{~m}$ above the Variscan unconformity and form wedge-shaped bodies on the downthrown sides of steep normal faults bordering the Rubio-Vilamu basins. Breccias grade into finer deposits in a vertical as well as a lateral sense, in directions at large angles to the approximately north-south striking bounding faults.

The breccia in the top part of section 9 shows many features similar to the ones described above. It is usually matrix-supported (silt-grade) and occurs in units a few meters thick which are interbedded with mudstone and pebbly mudstone. Pebble composition, rounding and sorting are the same as in the Rubio-Vilamu basins and in nearly all cases the beds also lack internal structures. The lower contacts of individual sedimentation units are non-erosional. The base of this breccia interval is not exposed and its three-dimensional shape is not well known. To the east and the west, however, sediments from the same part of Basinfill Sequence F (Figs. 9 and 19) are very fine-grained and field observations suggest that the breccias are bounded, as in the Rubio-Vilamu basins, by north-south striking high-angle faults.

\section{Interpretation}

The described contact between Variscan basement and breccia, showing almost in situ, dragged-apart cobbles and pebbles, strongly suggests that the base of the breccia unit is a fossil slope breccia. As for the remainder of the deposits, the pebble composition, the very poor rounding and sorting, the absence of any preferred orientation of the clasts, the occurrence of both framework- and matrix support, the lack of internal sedimentary structures and the non-erosive lower bedcontacts, point to short-distance mass flow transport.

The wedge-shaped geometry of the breccia bodies and their association with steep faults bounding the basin (only occurring immediately next to the faults on their downthrown sides) imply that transportation and subsequent sedimentation of scree breccia and debris flows were triggered by tectonic activity. Breccias form the lower part of the infill of rapidly subsiding grabens and are incorporated in the Grabenfill 
Facies Association. The breccia and mudflows of section 9 differ little from those previously described and are also classified with this association.

Throughout the breccia units the occurrence of FU sequences is interpreted as a result of waning energy conditions (Bluck, 1967; Steel, 1974).

\section{Conglomerate facies}

\section{Field data}

Conglomerate beds usually show great lateral extent, from some hundreds of meters to some tens of kilometers, with only minor changes of their properties. They always form the lower part of well-defined FU cycles, thus overlain by sandstones and silt. On the scale of an outcrop, scouring might occur at the base, but on a larger scale the beds are flat-based and indications for significant erosion are lacking. In a few cases there is a thin $(10-20 \mathrm{~cm})$ sandstone layer beneath the conglomerate bed.

Maximum bed thickness is a few meters (the only exception being the lower beds of the youngest basin-infill, see Fig. 12). Often the deposits are framework conglomerates, but in some cases the pebbles, which may have a diameter of up to a few $\mathrm{dm}$, are suspended in a matrix of usually coarse sand showing pink to red colours.

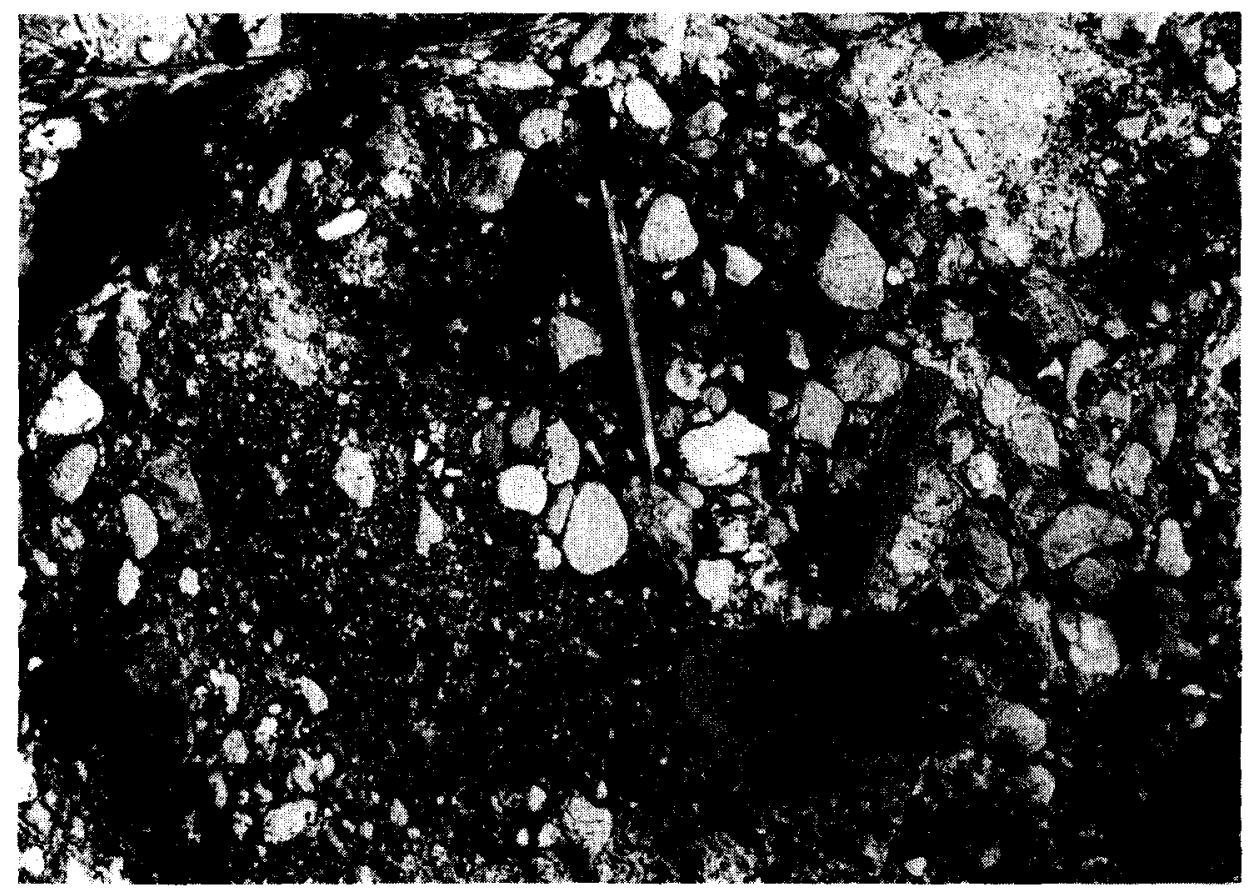

Fig. 4. Unstratified conglomerate in the lower part of Basinfill Sequence F in section 15. See Fig. 12 for location. Bedding plane just visible in upper left-hand corner. 
Sorting of the clasts ranges from poorly to well-sorted and is often in the range of moderately to moderately well-sorted. Rounding is in general poor but moderately well rounded pebbles do occur. Whenever limestone pebbles are present, the matrix of the conglomerate beds and all underlying rocks may be strongly calcified.

Although the above description holds for all conglomerates, they can be subdivided into two types: stratified and unstratified conglomerates. Unstratified conglomerates lack internal structure (Fig. 4). Usually there is no obvious internal grading but CU, FU and stacked CU-FU tendencies have been observed. Stratified conglomerates only occur within Basinfill Sequence F (Fig. 16) and are well exposed in section 15 . Bed thicknesses vary between 0.5 and $3 \mathrm{~m}$. Structures frequently are large-scale, high-angle tabular cross-bedding, organized in sets of a few $\mathrm{dm}$ to one meter in height. Lower bed contacts can be erosive but conglomerates are not noticeably restricted to channels.

\section{Clast-size distribution}

Figure 5 shows four representative clast-size distribution diagrams for conglomerate beds in section 15 . The distributions are markedly skewed towards their coarse tails, indicating that some lagging process was operative, producing an
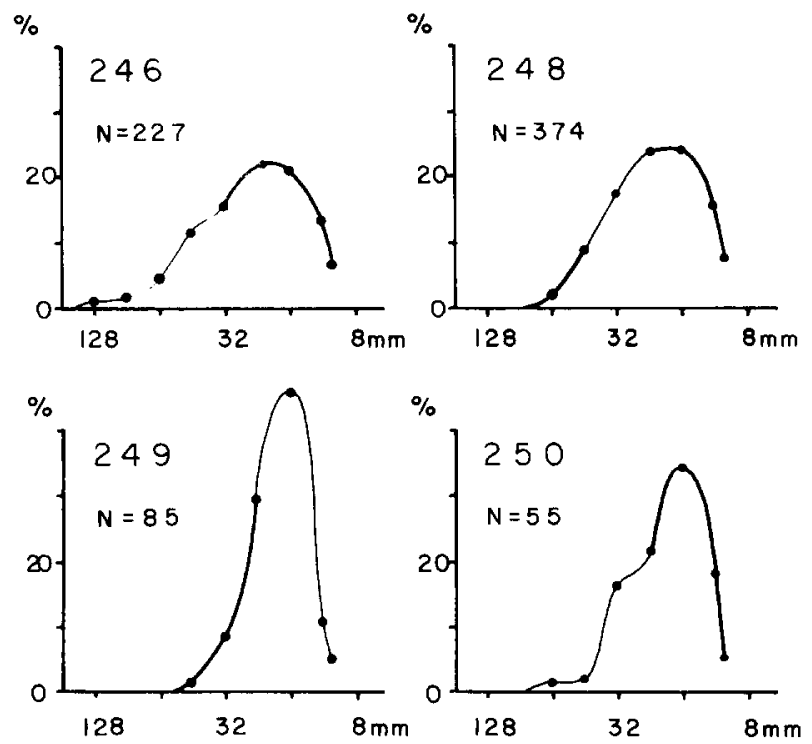

Fig. 5. Clast-size distribution diagram of four conglomerate beds in section 15 . Horizontal scale shows clast size, vertical scale gives percentages per clast-size class (each class covers $1 / 2 \phi$ unit). Thick lines indicate normal distributions of clast sizes as tested on log-normal graph paper. $N$ is number of measurements, numbers 246-250 are bed numbers in section 15 (see Fig. 12). (Note: as only clasts larger than $1 \mathrm{~cm}$ have been measured, the distributions have been cut-off at their fine tail which introduces some skewness towards the coarse tail. However, this effect is not large enough to explain the strong skewnesses shown in this figure.) 
enrichment in coarse clasts. Such lagging may be the result of two different processes: winnowing out or bypassing of fines (Bluck, 1967).

\section{Relation bed thickness / maximum pebble diameter}

Figure 6 shows the relation between maximum pebble diameter and unstratified conglomerate bed thickness in section 15. Two important conclusions can be drawn from the good correlation between these two properties (see Bluck, 1967; Steel. 1974):

(1) As is discussed by Blatt et al. (1972, p. 91), the Shield criterion relates the critical bottom stress of a water stream to the size of (quartz)particles in transport. Following the criterion, a linear relationship between grain size and competence of the stream can be expected for the conglomerates of the Peranera Formation. As, on the other hand, Fig. 6 shows a linear relationship between pebble diameter and conglomerate bed thickness, it follows that conglomerate bed thickness and stream competence are also linearly related. If we consequently take bed thickness to be a measure of the total volume of debris laid down in one depositional event, a relation is established between competence of the stream and total volume of sediment deposited from it. This, together with the observation that there is little or no evidence for erosion in the conglomerates, suggests deposition from "single-event" debris flows (Bluck, 1967).

(2) In alluvial systems pebble size decreases in directions away from the source (cf. Heward, 1978a). Because maximum pebble size is proportional to conglomerate bed thickness, bed thickness should also decrease in directions away from the source. with the consequence that the beds will be wedge-shaped. This property is not restricted only to conglomerate beds, as is illustrated in Fig. 7.

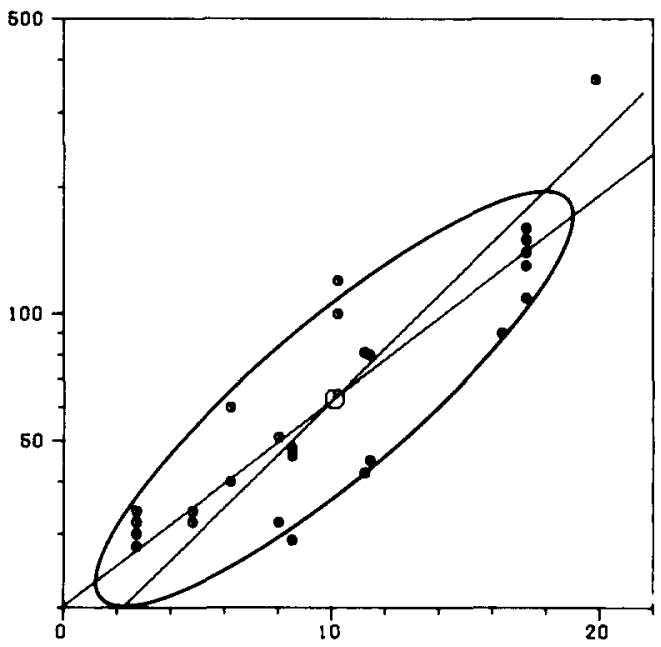

MAXIMUM PEBBLE DIAMETER (CM)

Fig. 6. Relation between maximum pebble diameter and conglomerate bed thickness for unstratified conglomerate beds in section 15 . Number of readings: 26 ; correlation coefficient: 0.88 . Regression lines $x$-on- $y$ and $y$-on- $x$ and $75 \%$ confidence ellipse are shown. 


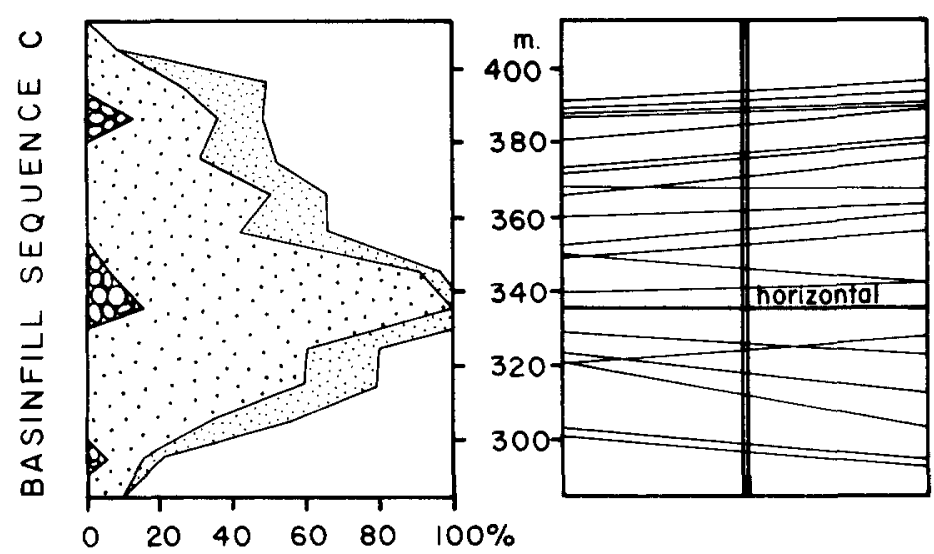

Fig. 7. Wedge-shaped arrangement of conglomerate- and sandstone beds in a major CU-FU megasequence of Basinfill Sequence C. Vertical scale represents height above base of section 15. The left part of the figure shows distribution of lithotypes (conglomerate, coarse sandstone, fine sandstone and silt, respectively). In the right part of the figure, lines show dips of individual beds after rotation of the thickest conglomerate bed in the megasequence (at $336 \mathrm{~m}$ ) to a horizontal position.

\section{Relationship of percentage limestone pebbles to maximum pebble size}

The lower part of Basinfill Sequence F within the La Seu basin mainly consists of thick (up to $10 \mathrm{~m}$ ) stratified and unstratified conglomerate beds usually containing high quantities of limestone pebbles, together with quartz-, quartzite- and sandstone pebbles (Fig. 12). To find an explanation for the strongly varying limestone pebble content, the ratio limestone pebble percentage/maximum pebble diameter has been

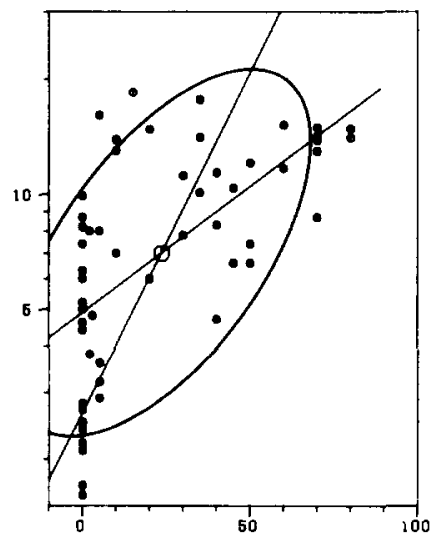

LIMESTONE PEBBLE PERCENTAGE SECTION 15

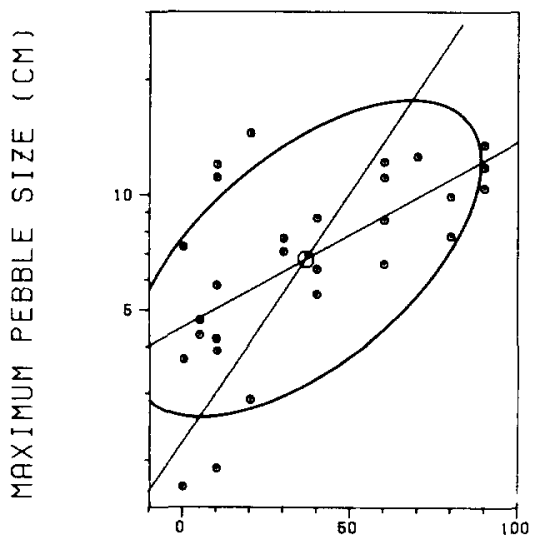

LIMESTONE PEBBLE PERCENTAGE SECTION 8

Fig. 8. Relation between limestone pebble percentage and maximum pebble size in sections 8 and 15 . Number of readings: 28 and 54, respectively; correlation coefficients 0.62 and 0.61 , respectively; $75 \%$ confidence ellipses and regressions $x$-on- $y$ and $y$-on- $x$ shown in both cases. 
determined in six sections. Figure 8 offers a representative selection of the results and there clearly is a positive correlation between the two properties. As clast size decreases with length of transport path and/or reworking, this relation will also hold for limestone pebble percentage. The conclusion is, of course, not a surprising one: limestone pebbles are known to be relatively sensitive to mechanical as well as chemical weathering.

The lowest units of Basinfill Sequence $F$ invariably show the largest pebbles and the highest limestone pebble content. Both properties, however, decline with height above the base of the basinfill sequence (Fig. 12). Consequently, the high limestone pebble percentages and large pebbles from the base of the basinfill sequence reflect mass-flow transportation over only short distances, without significant reworking, where stratified conglomerates in higher stratigraphic levels originate from reworking of older (unstratified) conglomerates and have been transported over relatively larger distances.

\section{Interpretation}

The unstratified conglomerate beds at the base of Basinfill Sequence $F$ have greater thickness and lateral extent than all other conglomerates in the La Seu basin. This property, together with the sharp, non-erosive bases, absence of internal structures such as imbrication, the clast/matrix relation, lack of sorting, the average clast size and presence of faint normal and inverted grading are all typical field aspects of a debris flow deposit. The relationship between maximum pebble size and bed thickness confirms this origin. Due to their mode of deposition and wedged shape, the conglomerates of the lower part of Basinfill Sequence $F$ are considered to be proximal alluvial fan deposits.

The other unstratified conglomerates of the La Seu basin are basically of the same type but are thinner and laterally less extensive compared to the ones interpreted above. Furthermore, their bases may be erosive, sorting is usually better and they contain fewer limestone pebbles. This type of sediment shows many resemblances to the "A type" conglomerates of Allen (1981), who interpreted them as fossil longitudinal bar deposits, i.e. thick gravel sheets with little topographic relief. In the Peranera Formation, the vertical as well as lateral grading of conglomerate into sandstone further supports their interpretation as longitudinal bars.

The erosive bases, lateral extent, FU sequences, often large clast size and the occurrence of large-scale cross-bedding within the stratified conglomerates point to deposition from competent, turbulent streams of low viscosity, spreading out over considerably large, flat areas. According to Heward (1978b) this type of stratified conglomerate must be situated in the mid-fan area.

Skewness of clast-size distribution and the maximum pebble size/limestone pebble content relationships (Figs. 5 and 8 ) are indicative of considerable reworking of earlier deposited sediments. This reworking must in this case be the result of scarp retreat and lowering of relief (Heward, 1978a, p. 685).

In conclusion, unstratified as well as stratified conglomerates form part of the 
"Alluvial Fan and Ephemeral Stream Facies Association", in which debris flows occupy a relatively proximal fan position, where other conglomerate types are the products of reworking of older sediment and occur on relatively low reaches of alluvial fans and, further basinward, in the ephemeral stream environment.

Pebbly sandstone and coarse cross-bedded sandstone facies

\section{Description}

Pebbly sandstone and coarse cross-bedded sandstone beds are usually continuous for hundreds of meters but can grade laterally into conglomerates or fine sandstones and eventually silt. They make up the greater part of the coarse-grained basinfill. The bases of the beds are almost exclusively erosive, scouring and channelling (with associated lag deposits) occur on a meter scale. Nevertheless, it has not been possible to recognize larger channels. Individual beds have thicknesses between 0.5 and $5 \mathrm{~m}$, and typically show red, pink and grey colours. Because of strong weathering of the beds, sedimentary structures are often hard to identify, but high angle trough cross-stratification seems to be abundant. The trough sets have heights of between some $\mathrm{dm}$ and $2 \mathrm{~m}$. In thick sandstone units it is often difficult to recognize the principal surface of accumulation, especially if cross-stratification is well developed.

In the pebbly sandstones, clasts can occur in a lag deposit and in strings along foresets or they appear to be randomly distributed. In the latter case pebbles have a maximum diameter of a few $\mathrm{cm}$ only. Clast composition shows little variation and comprises quartz, quartzite, sandstone and rare limestone pebbles. In some sandstones mudclasts have been found which were clearly derived from the underlying silts. The matrix is usually made up of fine and coarse sandstone. Sorting is moderate to moderately good, but pebbles are poorly rounded.

On top of cross-bedded units, even-laminated coarse sandstone layers may be found, generally lacking pebbles. The transition between the two is gradual, but takes place within a few $\mathrm{cm}$. Even-laminated, coarse sandstone may also alternate with silt levels. Within Basinfill Sequence F (Fig. 16) a special type of sandstone has been found showing well-developed lag deposits consisting of mudclasts, wellrounded pebbles and plant remains. The lag is overlain by cross-bedded coarse sandstone with distinct lateral accretion surfaces. The bases of the beds are erosive and a complete sequence is always fining upward. In all observed cases, paleocurrent directions are roughly perpendicular to the dip of the accretion surfaces.

\section{Interpretation}

The pebbly sandstone and cross-bedded sandstone facies represent "braided stream deposits" (Steel and Wilson, 1975) occurring below the intersection point of alluvial fans (Brookfield, 1980). The thin even-laminated sandstone units are interpreted as sheetflood deposits, which may develop downstream from braided stream deposits, but might also be laid down during overbank flooding of streamflood channels. In both cases deposition is from shallow waterflows. 
The pebbly sandstones and coarse cross-bedded sandstones make up the bulk of the alluvial fan and ephemeral stream facies association, but sheet-flood deposits belong to the basin floor association.

The special type of sandstones of Basinfill Sequence $F$, showing discrete accretion surfaces and lags, are part of point bar deposits of the basin floor association.

\section{Fine-grained sandstone facies}

\section{Description}

Fine-grained sandstones are volumetrically insignificant in the La Seu basin. Very often they form part of FU sequences, overlying coarse-grained sandstone and overlain by silts. Transitions in grain size are gradual, but may occur within a few $\mathrm{cm}$ or $\mathrm{dm}$. Maximum bed thickness is a few metres and sedimentary structures include (trough) cross-bedding, even-lamination or small-scale structures (ripples and cross-lamination). Sorting is usually moderate to good and rounding ranges from bad to moderate. Sometimes fine-grained sandstones do not form part of FU sequences and are then intercalated in silts. In this case they may be divided into two groups: Firstly, units less than $1 \mathrm{~m}$ thick, laterally grading into silts and/or coarser-grained sediments. In the latter case bed thickness may increase rapidly over short distances. The lower boundary is often slightly erosive, whereas the upward transition to silts is always gradual. Due to moderate to good sorting and poor outcrop conditions it is generally hard to detect any sedimentary structure, though even-lamination and (trough-?) cross-bedding have been found.

The second group consists of thin to very thin sandstones, occurring between thick (more than 5-10 m) siltstone units. They show no obvious relationship with coarser-grained sediments and possess sharp upper and lower boundaries. They may reach considerable lateral extent. Sorting and rounding are good. Sedimentary structures have seldom been recognized.

\section{Interpretation}

Fine sandstones that form part of FU sequences are thought to have been deposited during the waning current stage of a sedimentary event in an alluvial fan or braided stream environment. In this respect they are the fine-grained equivalent of coarse cross-bedded sandstones found on top of thick conglomerate beds. This type of fine sandstone belongs to the alluvial fan and ephemeral stream association.

The first type of fine-grained sandstone intercalated in silt, showing a relationship with coarser grained sediments, is interpreted as the lateral equivalent of braided streams. The second type, not showing such a relation, represents a lateral or downcurrent equivalent of sheetfloods or possibly a crevasse-type of intrafan or basin floor deposit. Most of the fine sandstones embedded in silts are attributed to the basin floor association, especially the type embedded in siltstone units. 
Silt and clay facies

\section{Description}

Silt is the most widespread lithofacies in the La Seu basin. In section 15 (Fig. 1), for example, $52 \%$ of the total rock volume is silt and in Basinfill Sequence F in this section there is no less than $79 \%$ silt. Clay occurs in only very limited amounts, at the very top of FU sequences. A hard red to purple colour is very characteristic of both lithotypes. Silts are usually massive, but sometimes vague even lamination and/or (trough-) cross-lamination is developed. At some levels rootlets are present, but well-preserved mottling has never been found. Hartevelt (1970) mentions the occurrence of badly preserved plant imprints in the upper part of Basinfill Sequence F. Mudcracks are often encountered, especially in the top of the Peranera Formation. Rain imprints are less frequent but they may be found at any level throughout the formation. Much the same holds for "puddle deposits", first described by Nagtegaal (1969).

A remarkable feature is the occurrence of caliches and calcretes in the fine-grained intervals. The first type of concretions is defined as isolated nodules of $\mathrm{CaCO}_{3}$, while calcretes occur in more or less continuous layers, often exhibiting wavy lamination. Sometimes it can be proved that the latter type, which is of very limited occurrence, developed from $\mathrm{CaCO}_{3}$ enrichment in fine sandstone, but in all other cases the

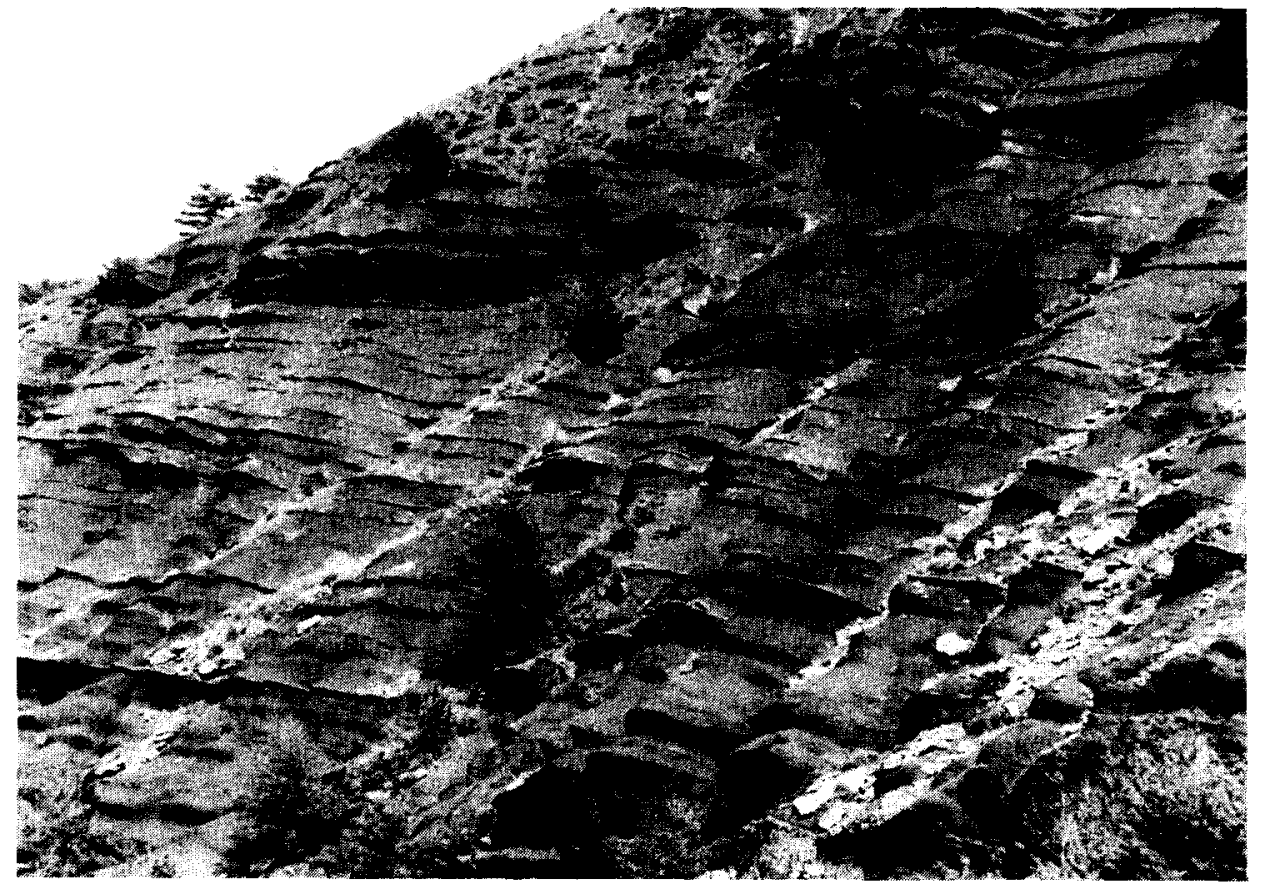

Fig. 9. Upper part of section 15 showing silts with intercalated very thin limestone layers of sabkha origin. 
original sediment was silt. Caliche-bearing profiles range in thickness from a few $\mathrm{dm}$ up to $40 \mathrm{~m}$ (cf. Fig. 12). Rocks from the top of Basinfill Sequence F may comprise very thin (less than $5 \mathrm{~cm}$ ) limestone layers which show great lateral persistency (Fig. 9). Eastwards, towards the Ges Fault Zone (Figs. 1 and 16), the limestones are gradually replaced by fine-grained sandstones.

\section{Interpretation}

The silts of the La Seu basin have been deposited as intrachannel- and/or intrafan- as well as basin floor deposits. The few sedimentary structures that could be found do not exclude this kind of genesis. It was already pointed out by Nagtegaal (1969), however, that very thick silt intervals might in fact be thick accumulations of wind-blown dust. Unfortunately, no evidence has been found for an aeolian origin and sand dunes are apparently absent in the La Seu basin. Collinson (1978a) suggest a possible aeolian genesis of Old Red Sandstone silts and discuss the difficulties in establishing criteria to identify fossil loess deposits: "Few ancient loess deposits older than the Pleistocene have been recognized. This is probably due to the rather featureless nature of such deposits and the consequent lack of positive criteria for their recognition". Whatever the nature of the silts, the occurrence of rootlets and sporadic plant remains, as well as the development of caliche profiles indicate soil formation. However, the preservation of rain imprints, mud-cracks, sedimentary structures, absence of mottling and bioturbation demonstrate there was no permanent vegetational cover in Permian times. The undisturbed nature of the puddle deposits, originated in dried-up pools, also points in this direction.

Semi-arid climatic conditions during deposition can be inferred from the strong red colouring of the sediments and the occurrence of caliche and calcrete (as well as some other of the criteria mentioned above). Both Nagtegaal (1969) and Gisbert (1981) propose environments of deposition which are climatologically and morphologically comparable to the present-day savannahs and steppes.

The thin limestone layers in Basinfill Sequence F probably form part of fossil sabkha deposits, developed by evaporation of intrabasinal ephemeral lakes occupying topographical depressions. The sandstones by which they are replaced towards the Ges Fault Zone are deposits of currents flowing from the both structurally and topographically high Ges Zone towards the sabkha lake.

Despite their uncertain mode of transportation and deposition, all sediments of the silt and clay facies are grouped with the basin floor facies association.

\section{FACIES ASSOCIATIONS}

The sedimentary facies described in the previous chapter are grouped into three facies associations: (1) the grabenfill facies association; (2) the alluvial fan and ephemeral stream facies association; and (3) the basin floor facies association. The 


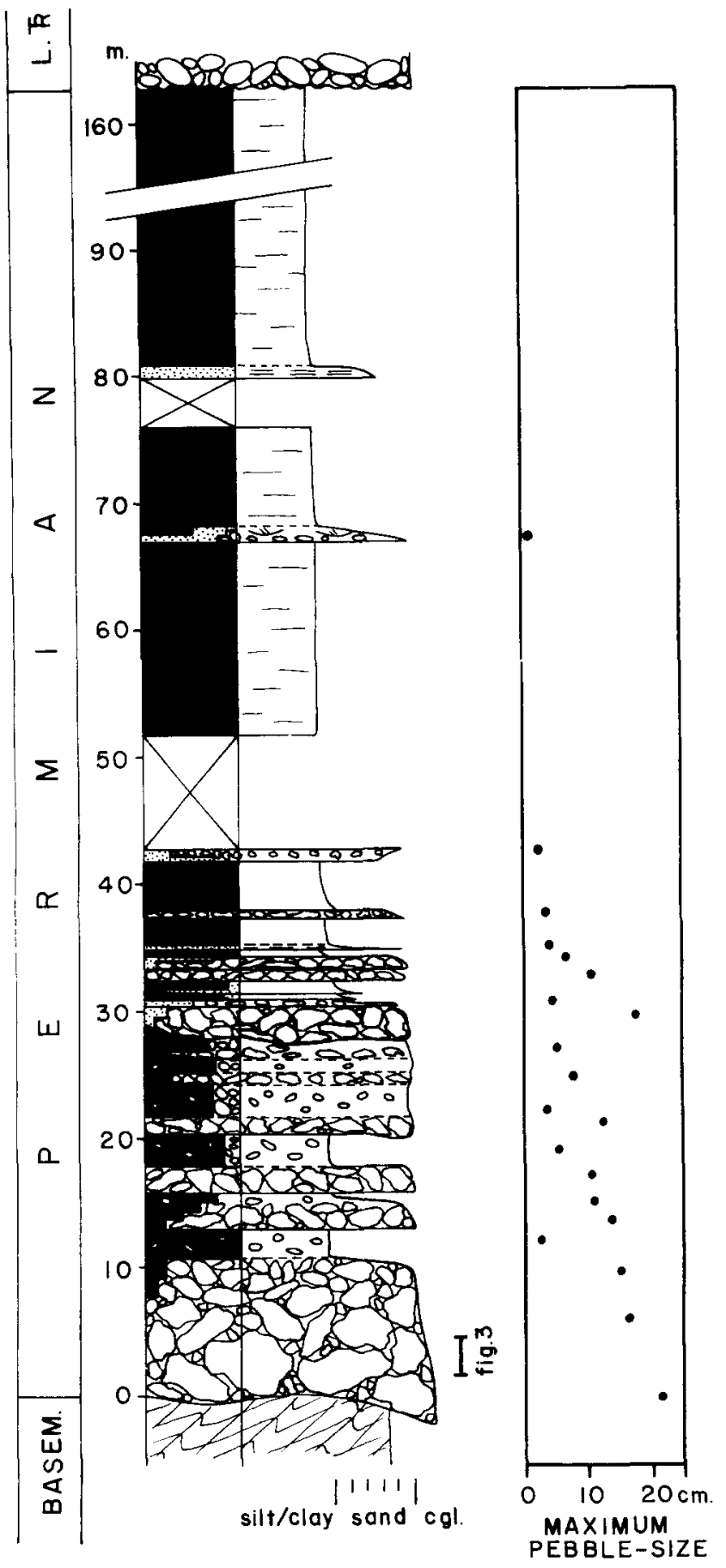

Fig. 10. Sedimentary log of section 3 situated in the centre of the Rubio-Vilamu basins. The section is composed of one large fining-upward megasequence classified with the grabenfill facies association. The lower $30-35 \mathrm{~m}$ of the section is occupied by deposits of the Breccia Facies with some associated pebbly mudstone, whereas the upper $130 \mathrm{~m}$ is dominated by silt (silt and clay facies). The photograph of Fig. 3 covers part of the lowest breccia unit just above the Variscan basement. 
occurrence of the first of these associations is basically restricted to the Rubio-Vilamu basins, whereas the second and third associations are typical for the La Seu basin. As their names suggest, the latter two represent the more coarse-grained and fine-grained part of the basinfill, respectively.

\section{Grabenfill facies association}

The typical grabenfill association shows a FU sequence, some hundreds of meters thick, comprising (from bottom to top): fossil scree deposits, debris-flow deposits (breccia and conglomerate), alluvial fan and ephemeral stream deposits (mainly sandstones) and finally a top of thick silts which may comprise as much as half the thickness of the whole fill (Fig. 10).

The development of this association is directly related to dip-slip movement on normal faults bordering the basins. An overall decrease of net displacement during sedimentation resulted in the remarkably well-defined $\mathrm{FU}$ sequences of the type described above.

\section{Alluvial fan and ephemeral stream facies association}

The alluvial fan and ephemeral stream facies association in principle comprises all sedimentary facies of the La Seu basin, arranged in stacked FU sequences, usually on a scale of 10's of $\mathrm{m}$. In view of this stacking and the reconstructed depositional environments and -mechanisms of the facies, deposition on alluvial fans and their downstream ephemeral stream and silty equivalents seems very likely. In a broad sense, grain size (and therefore the dominantly occurring facies) will be a function of "proximality" on the fan body, although the semi-arid climate with occasional catastrophic rainstorms, abundant debris in the source area and rapidly decreasing depositional energy during floods certainly had a strong impact on the differences in grainsize observed today.

Nevertheless, it is believed that thick, unstratified conglomerates, deposited by mass-flow processes hold a proximal position relative to the source area, whilst unstratified conglomerates deposited in longitudinal bars, stratified conglomerates and pebbly sandstones are transitional to (distal) coarse and fine sandstones and silts, thus resembling the threefold fan division of McGowen and Groat (1971). Gisbert (1981) arrives at a similar conclusion.

Upstream the alluvial fan and ephemeral stream facies association may grade into the grabenfill association and downstream it may pass into the basin floor association.

\section{Basin floor facies association}

The silt and clay facies is the main constituent of this association, but fine- and coarse-grained sandstones occur as well. The latter lithotype forms part of well-de- 
veloped point-bar sequences that originated from lateral migration of high-sinuosity rivers, occupying the basin floor between a period of violent basin-fill by alluvial fans and ephemeral streams, and the final fill of the La Seu basin by very thick silts (Basinfill Sequence F).

The sparsely occurring fine-grained sandstones are lateral or downstream equivalents of coarser grained sediments of alluvial fan or ephemeral stream origin.

The term "basin floor" as used here might be somewhat misleading: it is not defined as restricted to the lowest central part of the basin but must be attributed to any part of the basin exhibiting low gradients and receiving relatively fine-grained sediments. This usage of the term can be justified as follows: immediately after periods of strong tectonic activity, there was no, or only a narrow strip of basin floor left between coarse-grained deposits building out from fault scarps towards the basin centre from at least two sides (see section on paleogeography). When tectonic activity had ceased and only very low gradients existed in the La Seu basin, silts and some associated sands were deposited all over the basin so that the "basin floor" almost completely covered the whole basin.

\section{SEQUENTIAL ARRANGEMENT}

In a discussion about the origin of sedimentary sequences as a function of sedimentary and tectonic processes. Heward (1978a) suggested a threefold subdivision of sequences which is also applicable to the La Seu basin: (1) "sequences" in a specific sense, 1-10's of $m$ thick, consisting of a single bed or a series of related beds; (2) "megasequences", 10's-100's of m thick, consisting of arrangements of related beds and sequences; and (3) "basinfill sequences", consisting of arrangements of sequences and megasequences. In the case of the La Seu basin, megasequences are often separated by unconformity planes.

\section{Sequences}

Sequences almost without exception show an organisation of lithotypes in FU patterns. They are very well suited for investigation by the Transition Probability or Markov-analysis, in order to establish the relations between lithotypes in a vertical sense. An account of the method is given by Miall (1973), Harbaugh and BonhamCarter (1970) and Reading (1978).

In the sections 13,14 and 15, which are well-exposed over 570, 620 and $1490 \mathrm{~m}$, respectively, a total of 1604 transitions have been counted between the following lithofacies: (1) breccia and conglomerate; (2) pebbly sandstone; (3) coarse sandstone; (4) fine sandstone; (5) silt; and (6) silt with $\mathrm{CaCO}_{3}$ concretions. Figure 11 shows a schematic representation of the facies interrelations in the three sections. A significance test confirms the non-random nature of the Markov criterion $\left(X^{2}=404,3\right.$ with 19 degrees of freedom, limiting value $X^{2}=30.21$ at $95 \%$ confidence level. For 


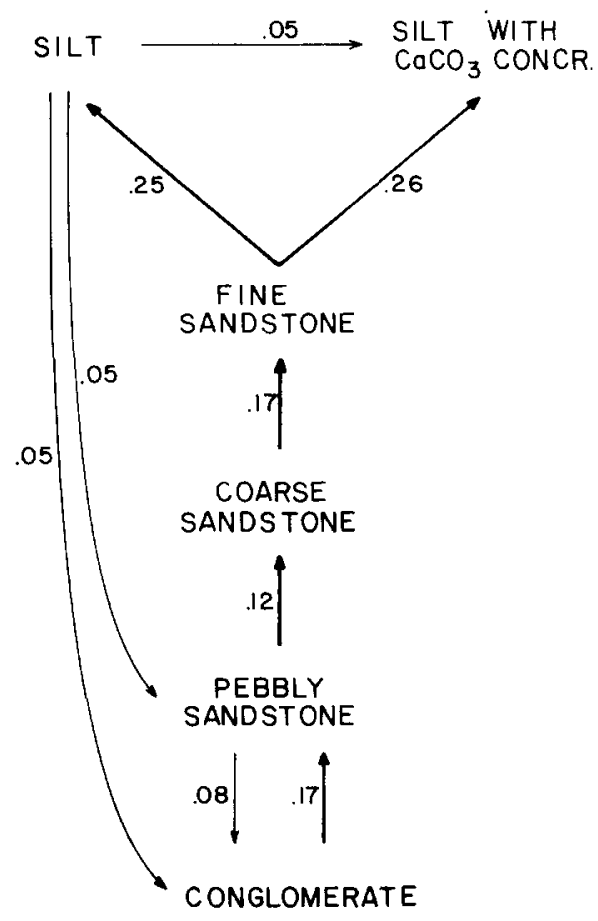

Fig. 11. Transition probability diagram for three sections $(13,14$ and 15) in the La Seu basin. Transitions with expected probabilities between 0 and 0.05 are not shown.

formulas and discussion see Miall, 1973, and Jones and Dixon, 1976). Similar transition probability tests were performed for all separate basinfill sequences of the three sections mentioned above, as well as for combinations of those. They all show the same basic pattern of Fig. 11, although slight differences exist between the 19 tests done.

The following conclusions can be drawn from the Markov analysis: (1) there is no marked cyclicity as transitions from fine-grained to coarse-grained lithotypes are ill-defined; (2) sequences are fining upward and stacked upon each other; and (3) the "complete" sequence 1-6 seldom occurs. Usually it is truncated at its top or base or both. There is no preference for a transition from fine-grained sandstone to silts with or without caliche concretions, and facies 1 and 2 may form a "closed set" (Harbaugh and Bonham-Carter, 1970).

Sequences are thought to be the products of single depositional events, their marked FU tendency resulting from waning current conditions. According to a hypothesis by Schumm (1973), such a depositional event may start off as a mass-flow caused by the failure of large debris masses in geomorphic thresholds, but may also have been caused by a single rainstorm giving rise to erosion and subsequent redeposition of (unstable masses of) older deposits. 
Whereas sequences always show a fining-upward trend, this is not exclusively the case with the megasequences, of which four types can be distinguished:

(1) Fining-upward megasequences. The lower part of Basinfill Sequence F, especially in section 15, shows a good example of this type (Fig. 12). Two megasequences are developed which grade from unstratified conglomerates through sandstones into silts. The lower megasequence is $50 \mathrm{~m}$ thick, and the upper one $500 \mathrm{~m}$, including more than $300 \mathrm{~m}$ of massive silt. Other examples are the FU megasequences of the graben-fill facies association of the Rubio-Vilamu grabens (Fig. 10).

(2) Coarsening-upward megasequences. There are few $\mathrm{CU}$ megasequences in the

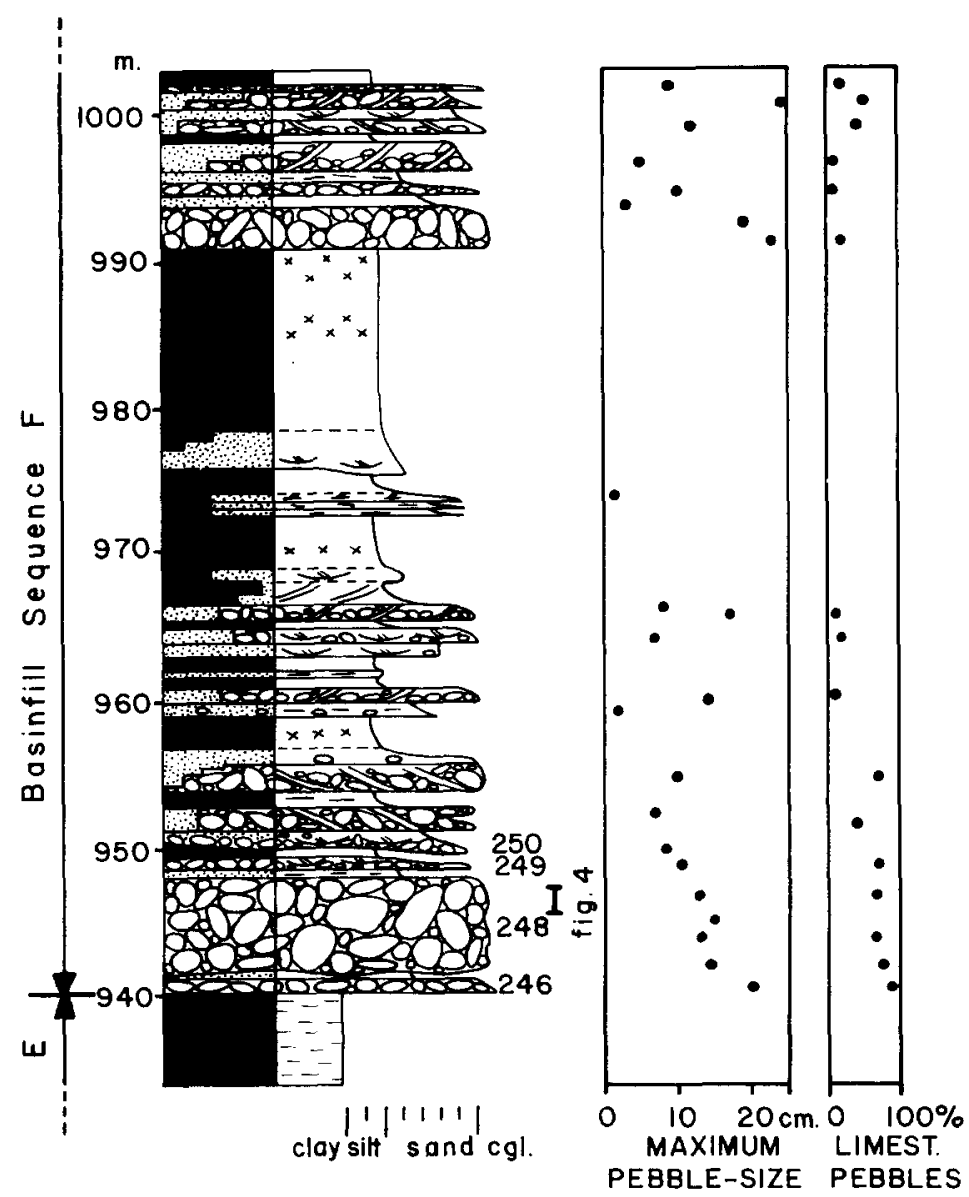

Fig. 12. Fining-upward megasequences in section 15. The lower megasequence is developed between 940 and $990 \mathrm{~m}$ while of the overlying one only the basal part between 990 and $1003 \mathrm{~m}$ is shown. Small crosses in silt/clay intervals indicate calcite concretions (caliches). Beds between 940 and $950 \mathrm{~m}$ are labelled; Fig. 5 shows clast-size distributions of these beds. 
La Seu basin which are not overlain by FU sequences (see next type of megasequence). Their occurrence is almost completely restricted to Basinfill Sequences A and $\mathrm{C}$ which form the lowest parts of the basin infill west and east of the Ges Fault Zone, respectively (cf. lower parts of Fig. 13).

(3) Combined CU-FU megasequences. These are characteristic for Basinfill Sequences B-D in the central parts of the La Seu basin. Figure 13 shows that those megasequences are thick, well-developed and can easily be traced laterally.

(4) Megasequences without clear CU-FU trends. In some parts of the basin no clear megasequences are developed and basinfill probably resulted from simple stacking of more or less identical sequences.

Fining-upward (mega-)sequences are thought to have been generated by vertical fault movements of waning intensity, resulting in decrease of the depositional

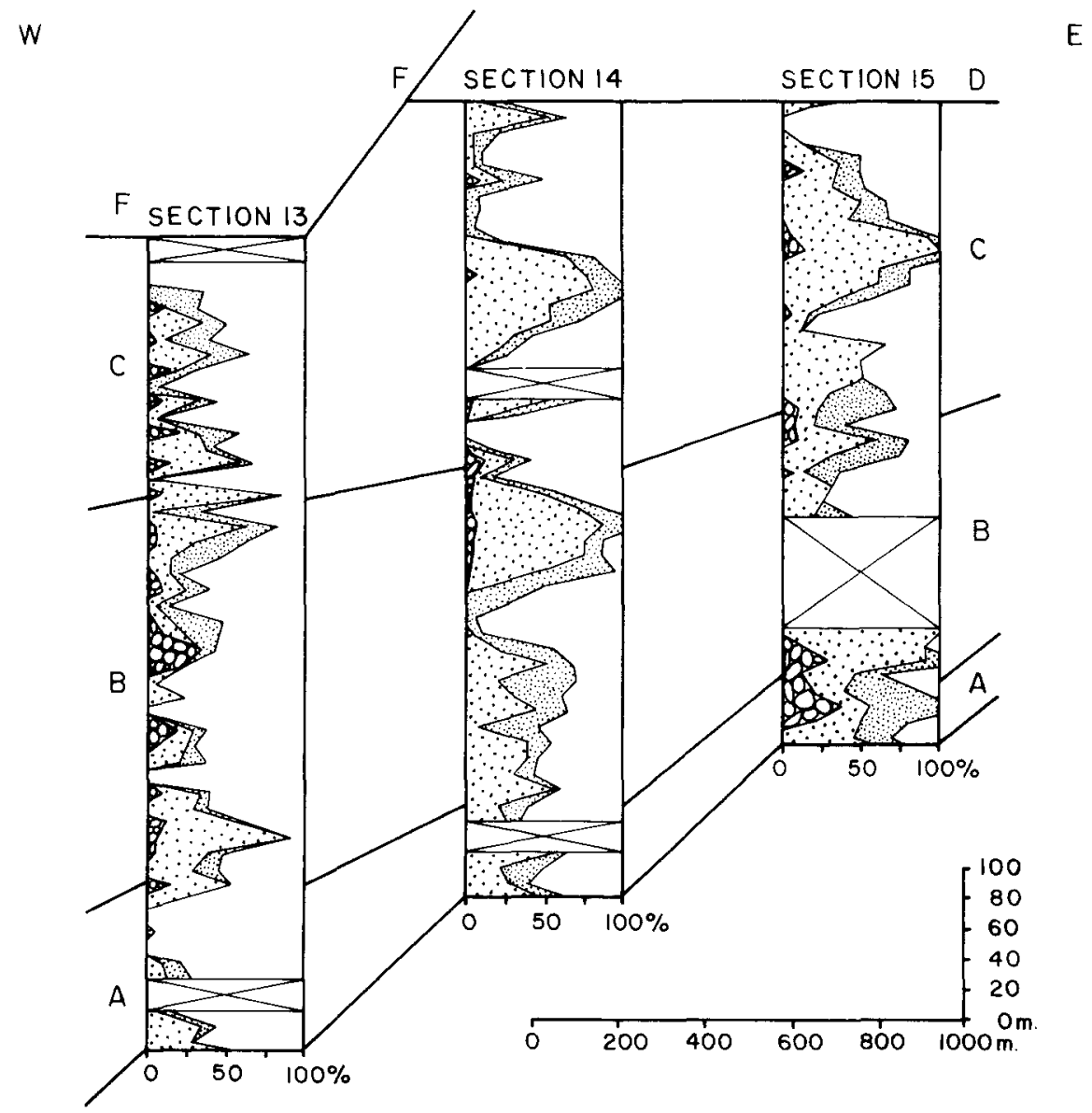

Fig. 13. Symmetrical CU-FU megasequences and their relations in sections 13,14 and 15. Ornamentation as in Fig. 7. Capitals refer to basinfill sequences. 
gradient (partly as a result of scarp retreat) causing finer detritus to be supplied to the depositional basin (e.g. Deegan, 1973; Steel, 1974; Steel and Wilson, 1975; Heward, 1978a). Apart from scarp retreat, sourceward shift of the locus of faulting (that is, widening of the basin) may aid the generation of FU megasequences. On the other hand, gradual but increasing subsidence of the basin floor will lead to progradation of fans, thus creating CU sequences (see Heward, 1978a, table 1).

Combined CU-FU megasequences might simply result from a combination of the kinematics described above for the generation of $\mathrm{CU}$ - and $\mathrm{FU}$ sequences, i.e. a gradual but increasing subsidence of the basin floor up to a certain maximum rate, followed by a decrease of the vertical fault movement which eventually drops to zero.

Surprisingly, most CU-FU megasequences in the La Seu basin show a marked symmetrical character (Fig. 13). This implies that a graph showing subsidence rate with time must be fairly symmetrical as well, because sedimentation is directly related to fault movement in semi-arid fault-controlled fans (maximum grain size is more or less proportional to subsidence rate). Figure 14 schematically pictures the variations in subsidence, subsidence rate, sediment thickness, sedimentation rate and maximum grain size with time. In section 26 a small-scale CU-FU sequence has been
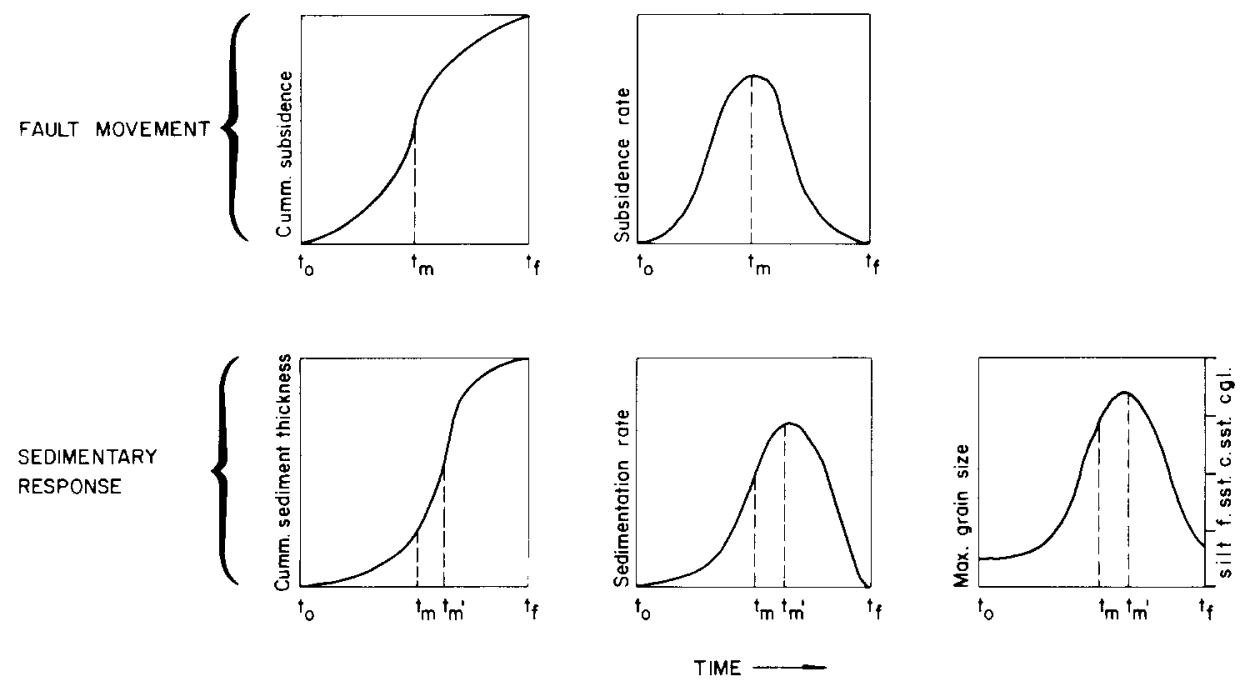

Fig. 14. Time-dependent parameters important to megasequence development. Basin subsidence (vertical fault movement) starts on moment $t_{0}$ and reaches its maximum velocity at moment $t_{\mathrm{m}}$. It is supposed that sedimentation can not completely keep up with subsidence around $t_{\mathrm{m}}$, so thickest beds and maximum grain sizes are laid down at moment $t_{\mathrm{m}}^{\prime}$, slightly later than $t_{\mathrm{m}}$. After $t_{\mathrm{m}}$ subsidence decreases and has dropped to zero at $t_{\mathrm{f}}$. Subsequently thinner beds and smaller grain sizes will be deposited and after $t_{\mathrm{f}}$ no gradient will exist anymore. This marks the end of mega-sequence development, but if the basin continues to sink at very low subsidence rates, thick, fine-grained levels of detritus may still accumulate. This effect may be augmented by post-depositional compaction. 
studied as well as the fault to which it is related. A situation map and cartoons depicting the probable genesis of this sequence are combined in Fig. 15.

The absence of any megasequence, caused by simple stacking of identical FU sequences, indicates that during sedimentation there was a delicate balance between basin subsidence, scarp retreat and depositional rate. This probably points to slow but constant lowering of the basin floor and the regular occurrence of spasmodic major flood events introducing sediment into the basin.
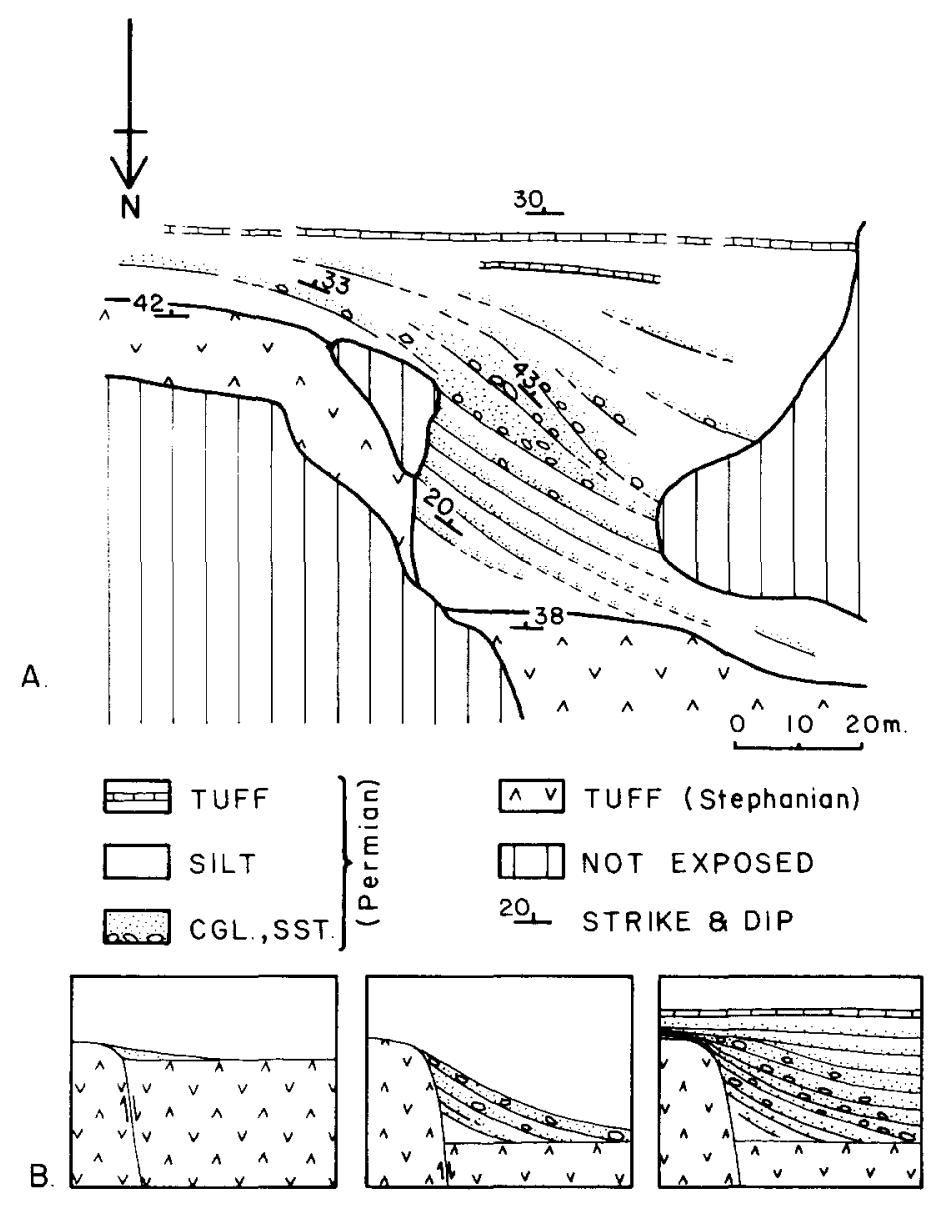

Fig. 15. Small-scale CU-FU megasequence in section 26. (A) Situation map showing distribution of lithologies, traces of individual (conglomeratic) sandstone beds and strike-dip data. As the regional structural dip amounts to $35^{\circ}-45^{\circ}$ towards the south, this map can also be read as an (oblique) profile. Fault throw is in the order of $30 \mathrm{~m}$. (B) Cartoons showing the probable genesis of the above structure. From left to right: situation just after fault initiation; last stage of fault development and flattening of relief after fault movement ceased. For further discussion see text. 

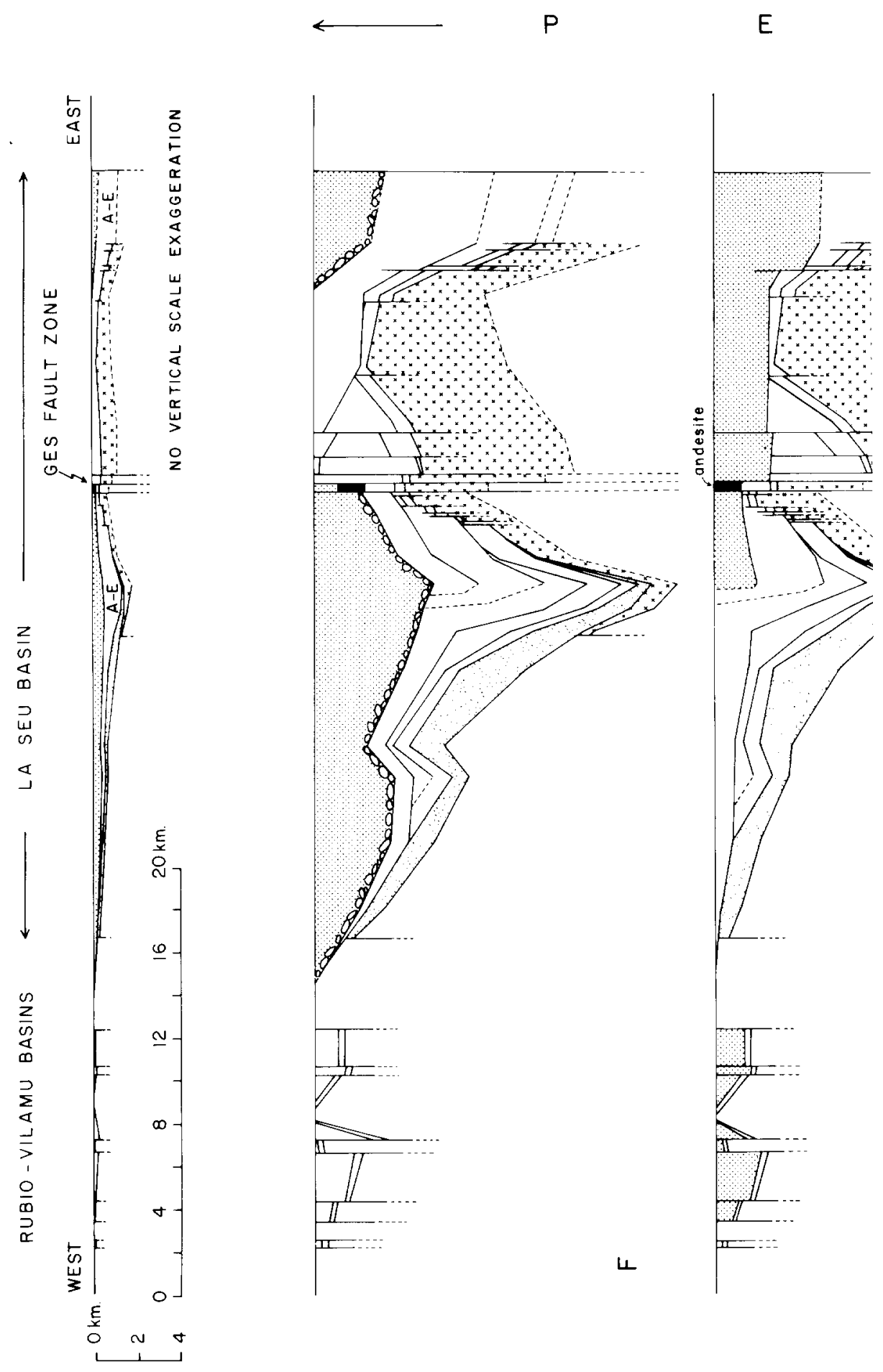



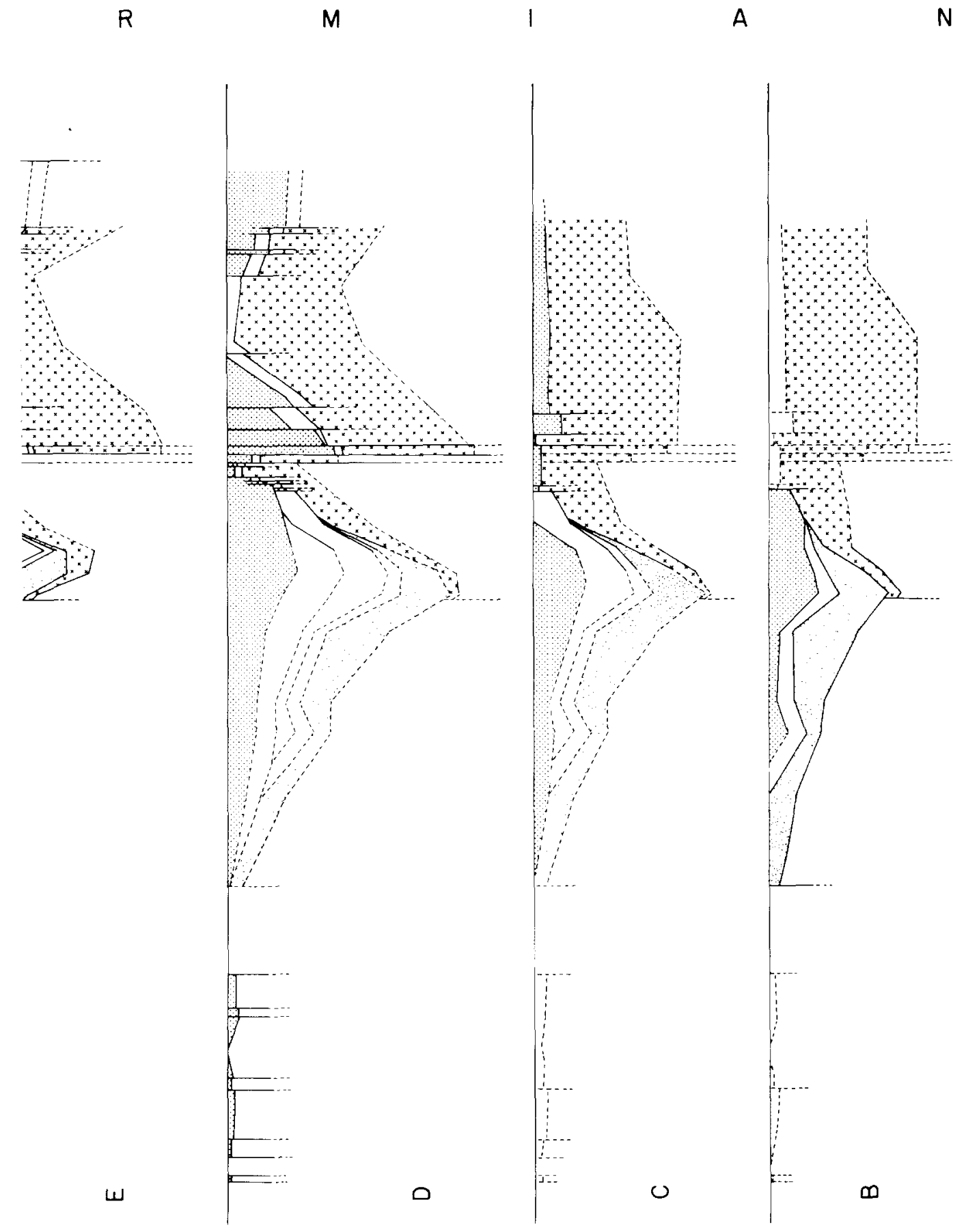



pp. $203-208$

$\leftarrow$ STEPHAN IAN
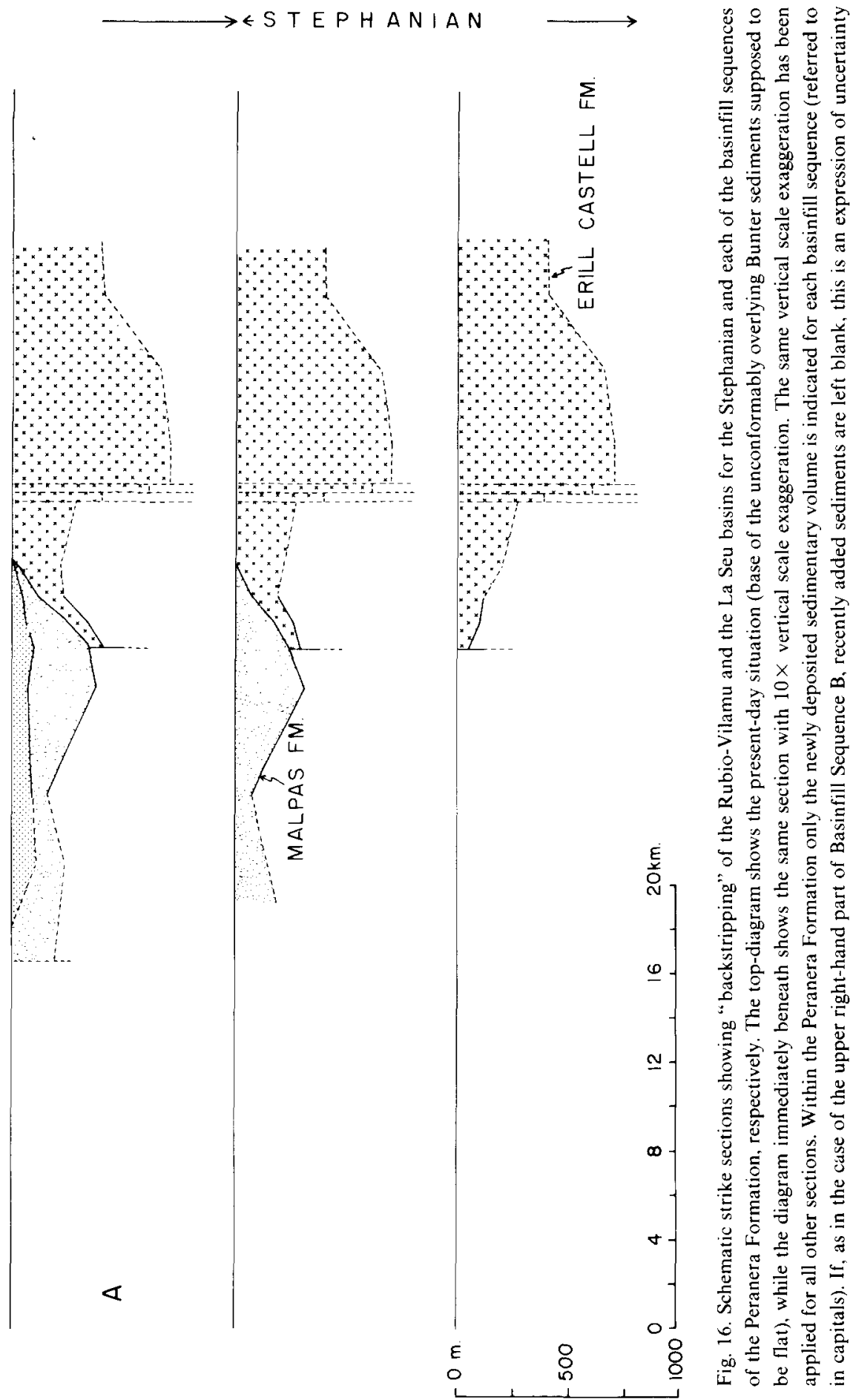

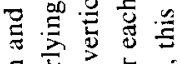

돌

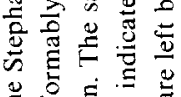

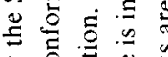

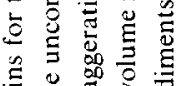

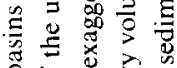

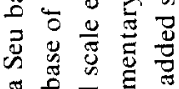

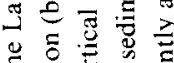

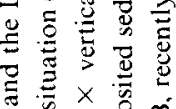

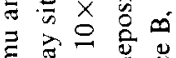

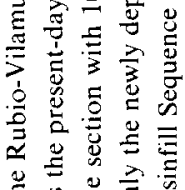

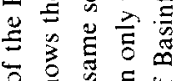

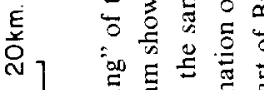

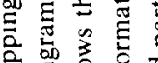

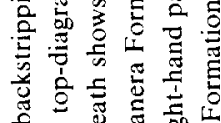

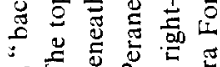

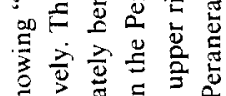

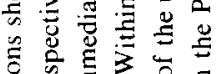

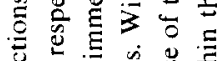
ญั

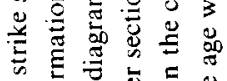

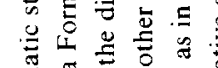

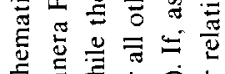

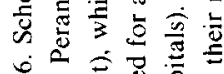

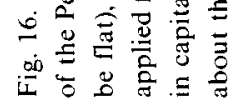





\section{Basinfill sequences}

In the Rubio-Vilamu and the La Seu basins a total of six basinfill sequences has been recognized (labelled $\mathrm{A}-\mathrm{F}$ in Fig. 16). The basinfill sequences are separated from each other by angular unconformities at the edges of the basin (Fig. 17), but in directions towards the center of the basin the unconformity planes may change character to (para-?) conformities. Basinfill Sequence A (only developed west of the Ges Fault Zone, Fig. 1) is built up mainly of fine-grained sediments. Wherever megasequences can be recognized, they show a CU pattern. This also holds for Sequence $\mathrm{C}$ east of the Ges Fault Zone, forming the basal part of the basin infill in that sector. Basinfill Sequences B-D are dominated by at least one symmetrical CU-FU megasequence, while within Basinfill Sequence E the CU-FU megasequences are asymmetrical and skewed towards their FU tail. Finally, Basinfill Sequence $\mathrm{F}$ exhibits one or more well-developed FU megasequences, as is also the case for the total grabenfill facies association of the Rubio-Vilamu basins (Fig. 10).

In conclusion, the following movement pattern of the floor of the La Seu basin can be deduced from sequentional sedimentological observations: A phase of gentle, but increasing subsidence was followed by several individual phases of initially

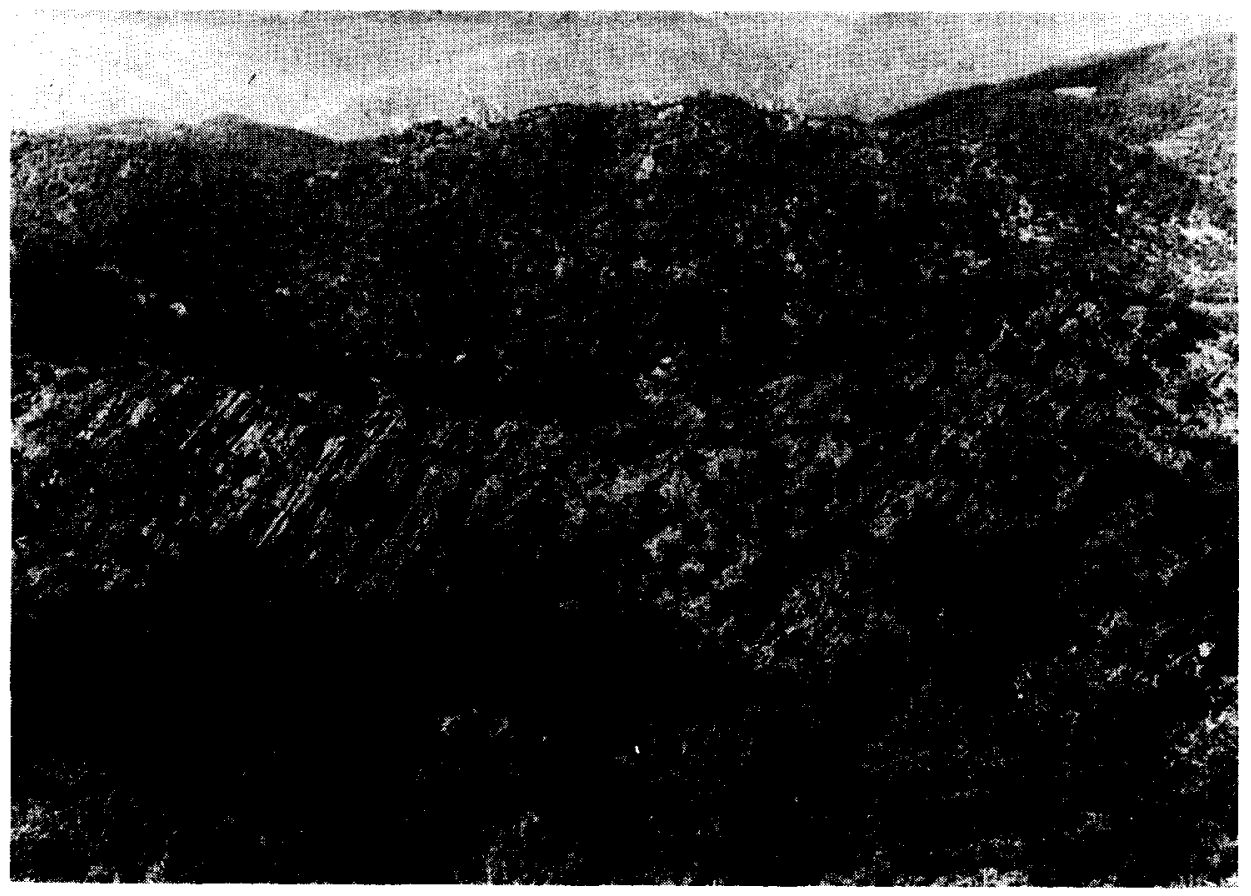

Fig. 17. Photograph showing the angular unconformity between Basinfill Sequences $C$ and D in section 15 (compare with Fig. 7). Picture taken from the crest of the andesitic rock mass in the Ges Fault Zone looking west along the strike of the section, see Fig. 1. 
strongly accelerating but subsequently decelerating subsidence and most of these phases became separated by (sometimes major) unconformities. The last stage of basin development is characterized by a sudden and strong downward vertical movement of the basin floor (thick conglomerates at the base of Basinfill Sequence F), followed by lower subsidence rates and finally a very gentle downwarp of the whole basin which was partly due to (differential) compaction.

The conglomerates of Basinfill Sequence $F$ show very high percentages of limestone-pebble content. In Sequences A-D hardly any limestone pebbles have been found, while in Sequence $E$ the limestone-pebble content is usually low, though in some sections it may be up to $70 \%$. This change in pebble composition suggests switching of available source area between deposition of Basinfill Sequences $E$ and $\mathrm{F}$, a view which is confirmed by paleocurrent analysis (see next section).

\section{PALEOGEOGRAPHY}

Figure 18 shows a series of paleocurrent diagrams for each of the six basinfill sequences of the Permian La Seu and Rubio-Vilamu basins, as well as the upper part of the Carboniferous Malpas Formation. The positions of sections 1-10 have been shifted somewhat to the south, thus correcting for the effects of postdepositional deformation. The traces of a number of faults which are believed to have been playing an important (synsedimentary) role in the La Seu basin have been added to these diagrams. Their possible existence has been mainly deduced from abrupt deviations in paleocurrent directions, other factors being observations on faults in the field, lined-up sudden changes in sedimentary facies, etc. The following conclusions can be drawn from Fig. 18:

(1) Paleocurrent readings in the Rubio-Vilamu basins are, almost without exception, oriented towards the south. They represent longitudinal transport in $\mathrm{N}-\mathrm{S}$ running, narrow grabens in which some coarse-grained lateral fills occur as well. The thin fine-grained sediments of section 1 (Fig. 1), which are to be situated north of the Rubio-Vilamu basins in a palinspastic reconstruction (Séguret, 1970), also show paleocurrent directions towards the south. They are considered to be the upstream equivalents of the Rubio-Vilamu graben-fills. On a large scale, the Rubio-Vilamu basins obviously acted as lateral feeder channels to the main (La Seu) depositional basin.

(2) In the central part of the La Seu basin paleocurrents of Basinfill Sequences A-E consistently run north, concentrated in a narrow corridor. In Basinfill Sequence $F$ paleocurrents run south. Outside of the central part, measurements indicate transport towards south and/or east. Sedimentation was apparently bounded by a $\mathrm{N}-\mathrm{S}$ striking feature, possibly a (half-) graben, which will be called the La Bastida graben after the nearby small village of La Bastida de Ortons.

(3) Most observations on sedimentary structures outside the central part of the basin show transport towards the south, which proves the existence of a gradient 


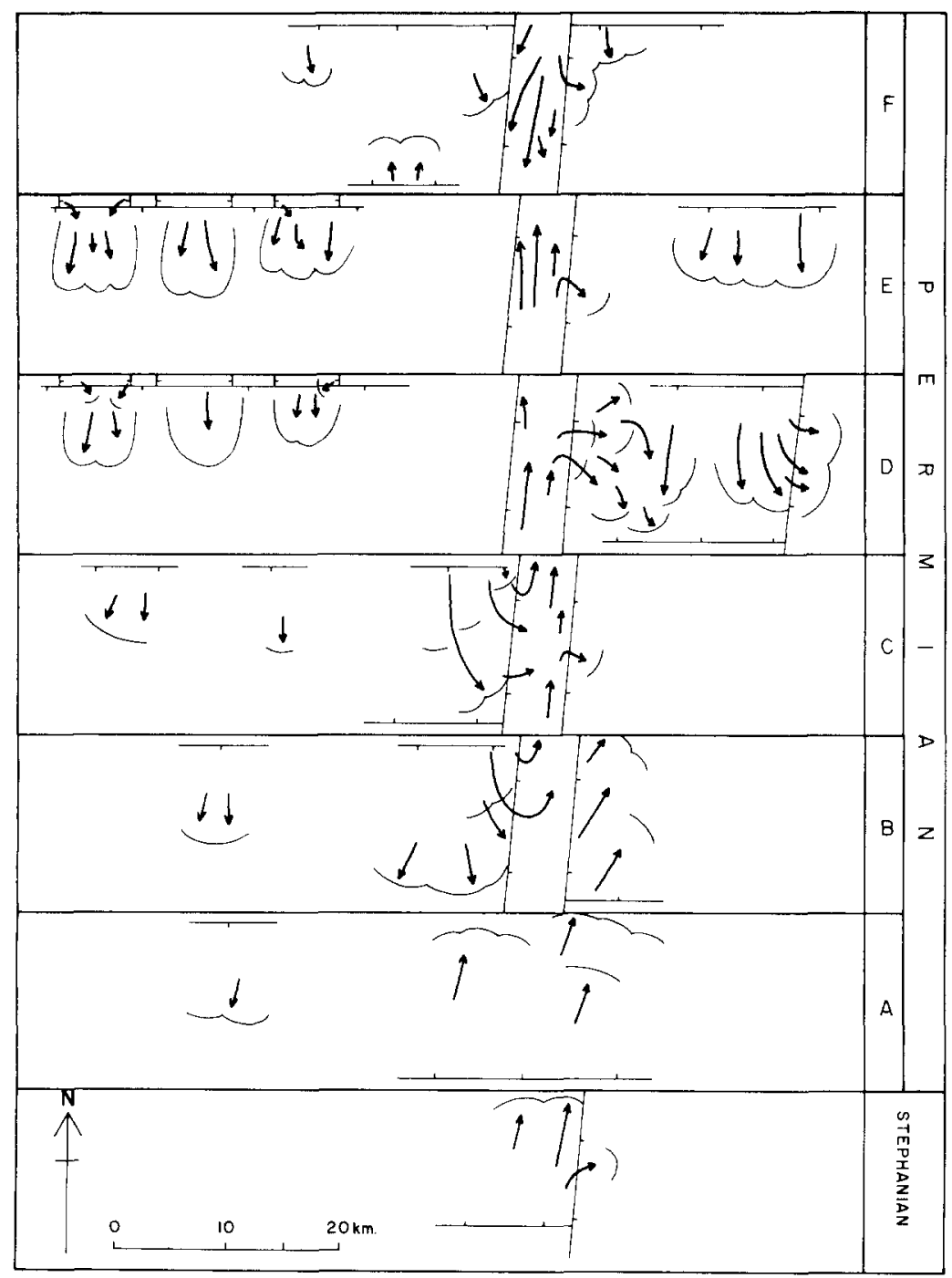

Fig. 18. Semi-quantitative representation of measured paleocurrent directions in the Rubio-Vilamu and La Seu basins. Length and density of arrows are a measure for the number of readings; the whole diagram is based on 417 paleocurrent measurements in the Stephanian and Basinfill Sequences A-F of the Peranera Formation. The positions of normal faults, their sense of movement (equal to the dip direction of the fault planes indicated by barbs) and possible outline of alluvial fans are based on interpretation, mainly from paleocurrent directions and their sudden deviations, as well as some additional evidence (present-day positions of faults, geometry of alluvial wedges, etc.).

from the north, the nature of the deposits pointing to a relief of tectonic origin. This suggests the presence of one or more long, individual, E-W striking faults towards the north, downthrowing to the south. It is remarkable that the alluvial fans and 
ephemeral stream bundles which built out towards the south show very little dispersion of current directions. This effect can be easily explained by imagining coalescing fans forming a bajada (Collinson, 1978b) instead of half-cone-shaped fan bodies building out from separate fanhead canyons. Furthermore, the lack of dispersion of paleocurrent directions suggests straight, continuous fault traces at the surface.

(4) In some cases, paleocurrent directions suddenly change orientation towards the southeast, east or even northeast. As those changes in directions occur along more or less straight N-S striking lines (Fig. 18), fault tectonics are held responsible for this feature. A satisfactory explanation would be the presence of normal faults with eastwards downthrown but westward tilted blocks.

STRUCTURAL ORGANIZATION OF LA SEU AND RUBIO-VILAMU BASINS

\section{Northern basin fault}

As has been argued before, this limiting fault must be situated somewhere south of the Rubio-Vilamu basins and north of the present outcrop area of the La Seu basin. Towards the east, sections 29 and 30 show sediment thicknesses of only 10 and $70 \mathrm{~m}$ respectively, while section 28 , only $1.5 \mathrm{~km}$ further south (Fig. 1), has a total thickness of $1100 \mathrm{~m}$. This means that the bounding fault has to pass between those sections. Together with lineament patterns in the basement it leads us to postulate a rather straight, more or less $\mathrm{E}-\mathrm{W}$ striking fault bounding the La Seu basin to the north.

\section{Southern basin fault}

The precise position of this fault is less clear. Towards the west it is assumed to be covered by a large allochthonous tectonic unit as described by Séguret (1970). To the east however, there are two important indications concerning its position. Firstly, the grabenfill sequence which forms part of Basinfill Sequence $F$ in section 9 is composed of coarse-grained mass-flow breccia with paleocurrent directions towards the north (see section on Breccia Facies). The marginal fault must therefore have been situated close to the present position of the top of section 9 .

A second, and more important indication, comes from a large-scale gravity-induced structure, developed below Basinfill Sequence F in sections 13, 14 and 15. Figure 19 shows this structure on a map which has been oriented in such a way that it can also be regarded as an oblique profile through the fold due to the regional $45^{\circ}$ southward dip. The base of Basinfill Sequence D rests conformably upon a thick silt level which here forms the top of Basinfill Sequence C. This level obviously acted as a décollement horizon enabling the sedimentary pile above it to slide down from the basin edge. No large-distance transport occurred, however, as in section 15 Basinfill 
Sequence D is still rooted to its "basement". The structure therefore must be a large flapfold, the upper foldhinge of which was removed by subsequent erosion as the base of Basinfill Sequence F cuts obliquely through the upright limb of the fold.

Reconstruction of the fold-axis shows that it was close to horizontal and had a $100^{\circ}-280^{\circ}$ direction before later deformation. Additionally, the asymmetry of the fold indicates a movement of its crest towards the north.

It is suggested, in conclusion, that the southern marginal fault of the La Seu basin lies directly south of the present-day outcrop of the Permian rocks, has a rather straight outline and strikes approximately east-west.

\section{Ges Fault Zone}

At the present level of erosion this fault zone consists of three main and several subsidiary branches defining a total width of $4 \mathrm{~km}$ (Figs. 1 and 16). It has been named after the hamlet of Ges, southeast of La Seu d'Urgell. Figure 16 clearly reveals the importance of the Ges Fault Zone in the development of the La Seu basin. It was already active in Upper Carboniferous times (but the structure may be much older; see Zwart, 1979, and Mey, 1968); it had great impact on Permian sedimentation and was reactivated during the Eocene. It stands out as an obvious

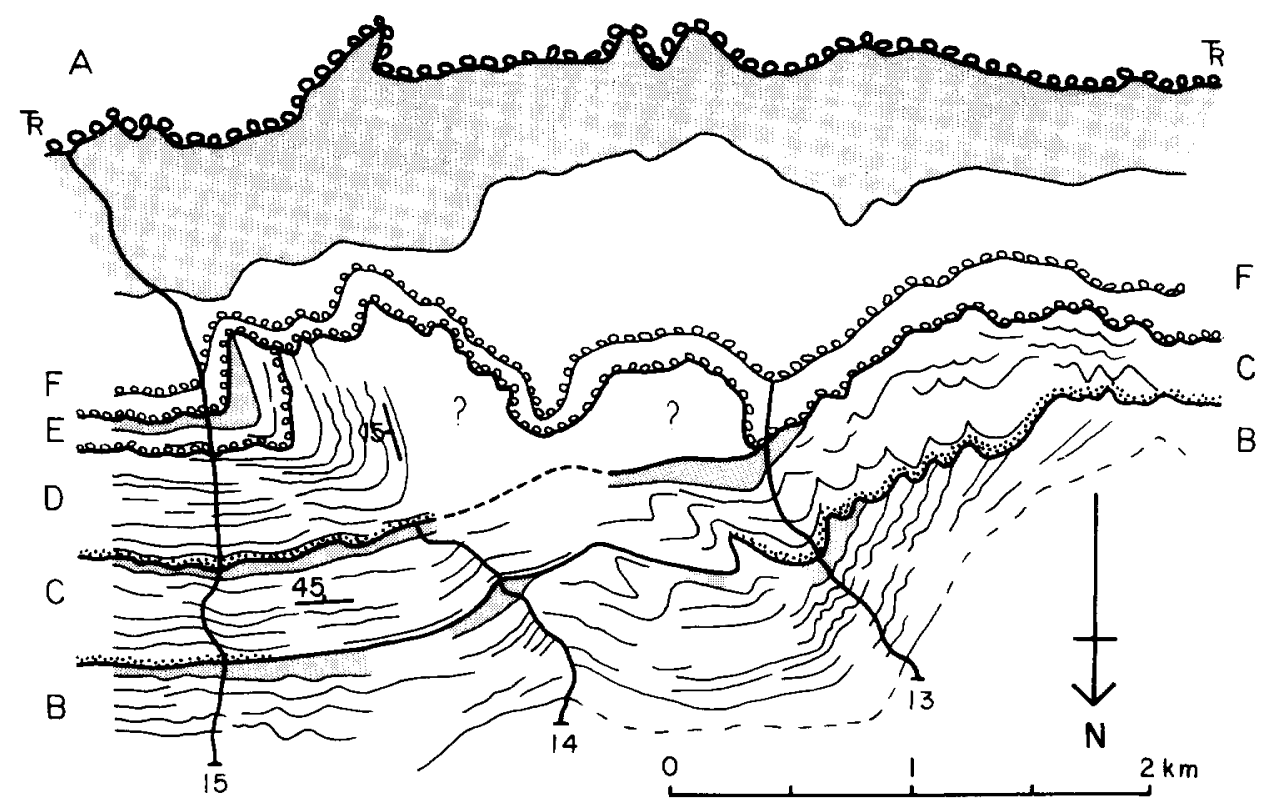

Fig. 19. (A) Map (drawn from aerial photographs) of flapfold in the central part of the La Seu basin. This gravitational structure developed following detachment along the southern boundary fault of the basin and became deeply eroded before deposition of Basinfill Sequence F. For further discussion see text. Also note the angular unconformity west of section 13. Irregular bed traces in Basinfill Sequences B and C west of section 14 result from badland erosion. 

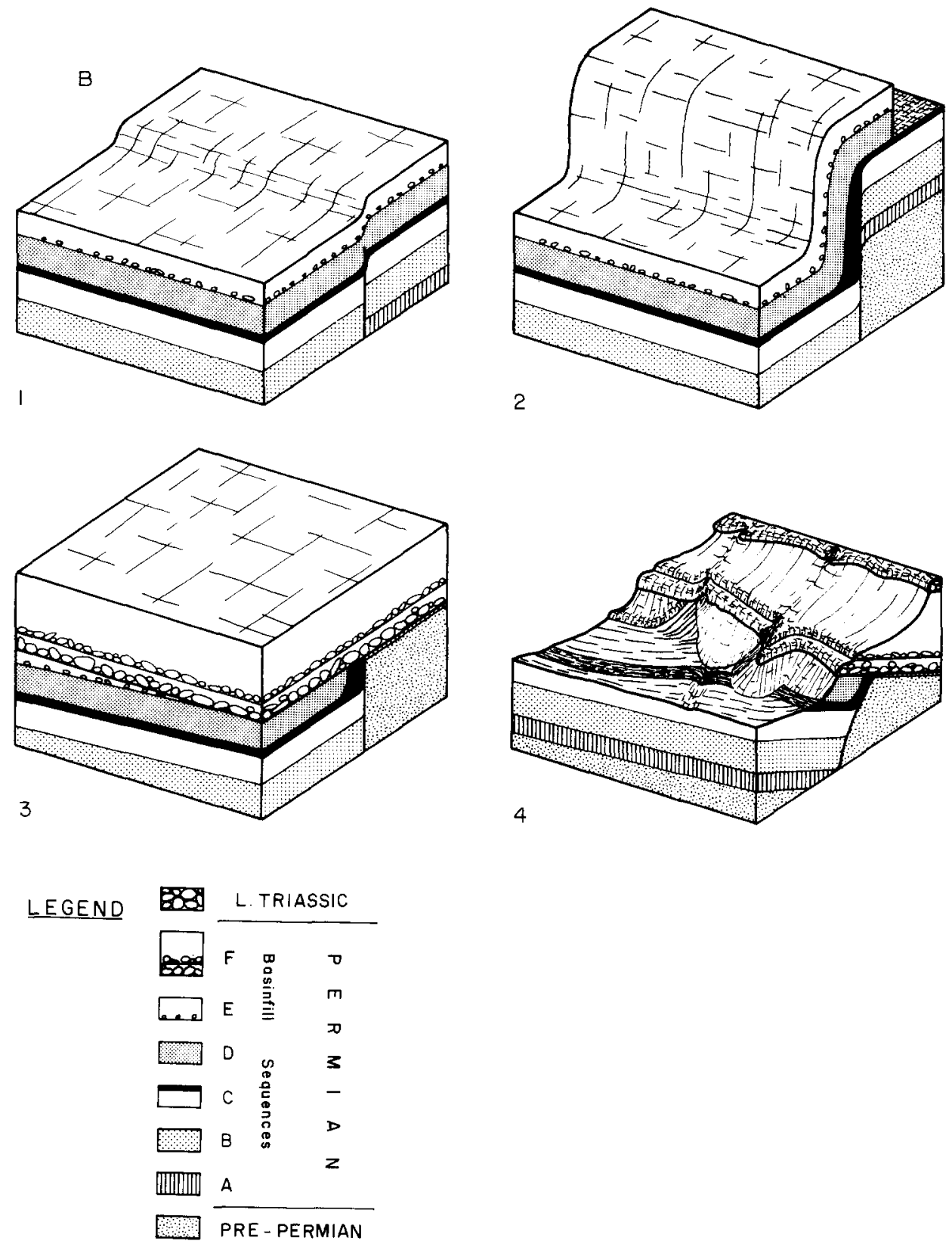

Fig. 19 (continued). (B) Blockdiagrams showing the development of the flapfold. Block 4 gives the recent situation. 


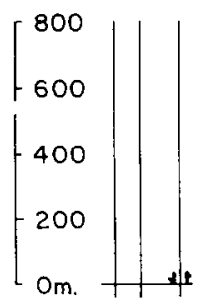

B

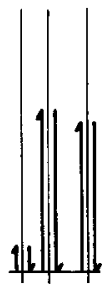

D

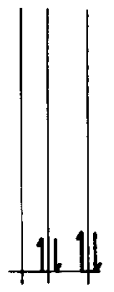

E

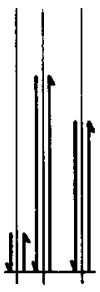

F

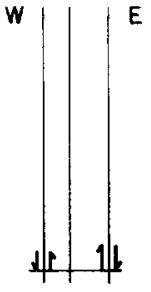

NET

Fig. 20. Dip-slip movement along the three main branches of the Ges Fault Zone during the Permian. Capitals refer to basinfill sequences; the right-hand part of the diagram shows the net vertical offset. Width of the fault zone is approximately $1 \mathrm{~km}$.

N-S lineament on Landsat and Skylab images in which it can be traced over a distance of about $10 \mathrm{~km}$. (The fault zone may nevertheless extend over a much larger distance as it is covered by allochtonous Devonian units in the north and by Mesozoic sediments in the south.) Figure 20 depicts the reconstructed net vertical offsets for individual basinfill sequences along the three main branches of the fault zone. During deposition of a single basinfill sequence, cumulative net offsets along the whole Ges Fault Zone may have been in the order of $1000-1200 \mathrm{~m}$, but for the complete Permian section (right part of Fig. 20) the net effect only consists of a minor uplift of the fault zone itself, the amount of which is probably close to the error limits involved in the reconstruction. So, in spite of the occurrence of considerable movements at distinct time intervals, there was no net vertical offset during the Permian.

The maximum amounts of reconstructed offset suggest that the Ges Fault Zone must reach deep into the crust. This view is confirmed by the outpouring of lavas of mainly andesitic character after deposition and erosion of Basinfill Sequence D. They are of the same composition as tuffs and lavas from the Stephanian Erill Castell Formation described by Morre and Thiébaut (1964), occurring stratigraphically below the Permian deposits. Hartevelt (1970) incorrectly attributed the crystalline rocks of the Ges Fault Zone to the Stephanian too, but the intercalation of lavas between Permian sediments and the nature of the contacts prove that they must be younger.

In profile the Ges Fault Zone shows similarities to typical strike-slip fault systems (cf. Miall, 1978), but, unfortunately, conclusive data on the horizontal movement along the Ges Zone are lacking, although a substantial dextral offset cannot be excluded. Therefore, it is tentatively proposed that due to negligible net vertical movements and resemblances with well-described strike-slip systems, the Ges Fault Zone acted as an oblique-slip zone with a large horizontal component.

\section{Migration of depocentre}

The profiles of Fig. 16 show that the position of accumulation of maximum 


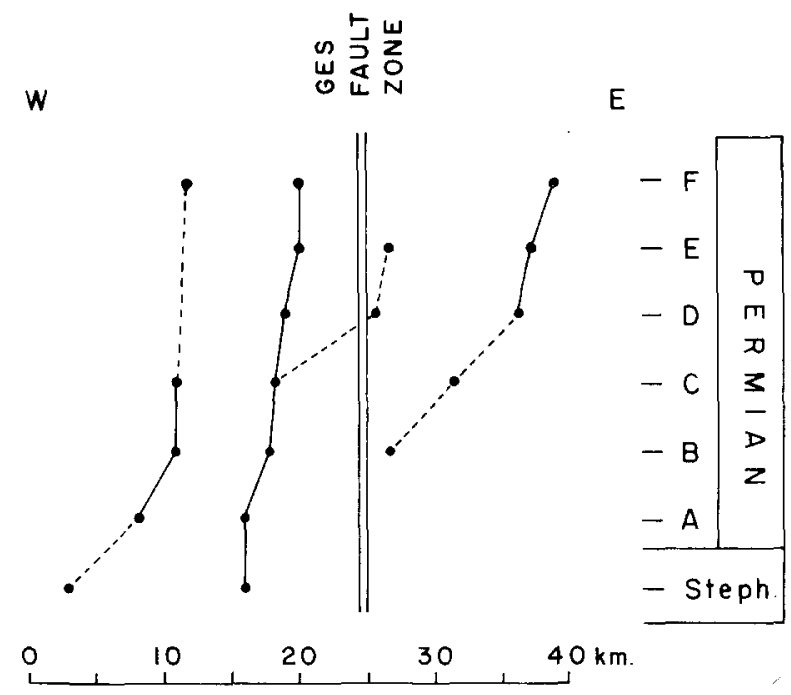

Fig. 21. Migration of depocentre in the La Seu basin with time. Data mainly taken from Fig. 16. Capitals refer to basinfill sequences.

sediment thickness (after compaction, deformation and erosion) shifted through time in the La Seu basin. Figure 21 demonstrates this feature in more detail. It is clear that the migration of the depocentre invariably occurred towards the east, but that the Ges Fault Zone acted as a barrier against this dynamic evolution. The main depocentre of the basin never crossed this barrier, but a newly nucleated depocentre jumped over during deposition of Basinfill Sequence D. The distances over which the depocentres migrated (4.5-12.5 km of proven minimum migration) are considerable compared to the maximum preserved thickness of sediment $(1.5 \mathrm{~km})$. If the ratio minimum translation distance/maximum preserved sediment thickness is taken to be a measure for the net strike-slip/net dip-slip ratio, it follows that the latter must be in the order of 3-8, or an average 5.5. This estimation must, however, certainly be a conservative one, because the La Seu basin was bounded to the north as well as to the south by blocks which moved in opposite directions with respect to the basin. Therefore, the net movement along the whole strike-slip system may have been much larger than the recorded translation distance of the depocentre. Figure 22 illustrates this principle.

A relatively large, unidirectional and uniform translation of the locus of maximum sediment accumulation in a sedimentary basin with time is considered to be indicative of a strike-slip dominated fault-bounded basin (Steel and Gloppen, 1980). A similar shift of depocentre towards the east can be concluded from a reinterpretation of one of Nagtegaal's (1969) profiles through a sedimentary basin of Permian age some $50 \mathrm{~km}$ west of La Seu d'Urgell. 


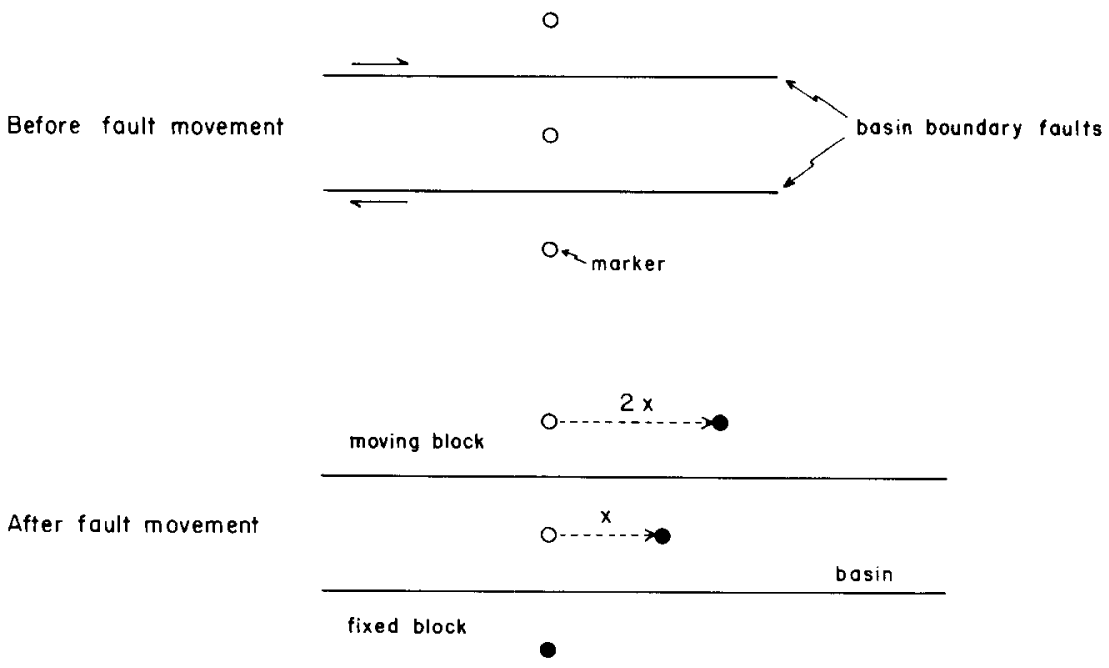

Fig. 22. Diagram showing the theoretical relationship between migration of a marker (e.g. depocentre) within the La Seu basin and the net strike-slip movement along the boundary faults of the basin. If identical offset is assumed for both faults, the total offset will amount to a distance $2 x$ while the marker within the basin only travelled over half that distance.

\section{Relations between basinfill sequences}

Basin development in an oblique-slip zone can only occur in a situation of transtension (strike-slip with superimposed extension; Harland, 1971), characterized by normal faulting, drape folding and volcanicity (Reading, 1980). On the other hand, folding, uplift and subsequent erosion points to transpression (strike-slip with superimposed compression; Harland, 1971). In the case of the La Seu basin, episodes of sedimentation with associated volcanicity and gravity folding have been followed by periods of deformation (involving uplift and folding) and erosion, thus separating six basinfill sequences by distinct unconformities. It follows that the combined depositional and structural histories of the La Seu basin show that a number of alternating transtensive and transpressive regimes were responsible for its development. It is felt that such alternations of different structural regimes result from continuous movement along locally slightly curved strike-slip faults (see Reading, 1980). In this respect it is significant that along the strike of the basin the unconformity planes may change character over short distances into conformable contacts, thus marking the transition from transpressive to non-transpressive regions.

Normal faults perpendicular to the basin axis

Numerous small- and medium-scale, north-south striking faults have been recog- 
nized in the field. Unfortunately there is often no control on the importance of possible strike-slip components. An example of a small-scale north-south striking fault from section 26 has been described in a previous section, see Fig. 15. Analysis of paleocurrent directions has revealed the existence of some major north-south striking normal faults separating westward tilted blocks (Fig. 18), which also points to the existence of an extensional stress regime during deposition of each of the basinfill sequences. As these normal faults have not been recognized in the field. their positions in Fig. 23 can only be tentative.

Soula et al. (1979) and Bixel and Lucas (1983) explain the formation of Stephano-Permian N-S directed (half-)grabens in the western Pyrenees by the wedging open of older $\mathrm{N}-\mathrm{S}$ Variscan faults as a result of $\mathrm{E}-\mathrm{W}$ left-lateral simple shear.

\section{Ges Fault Zone}
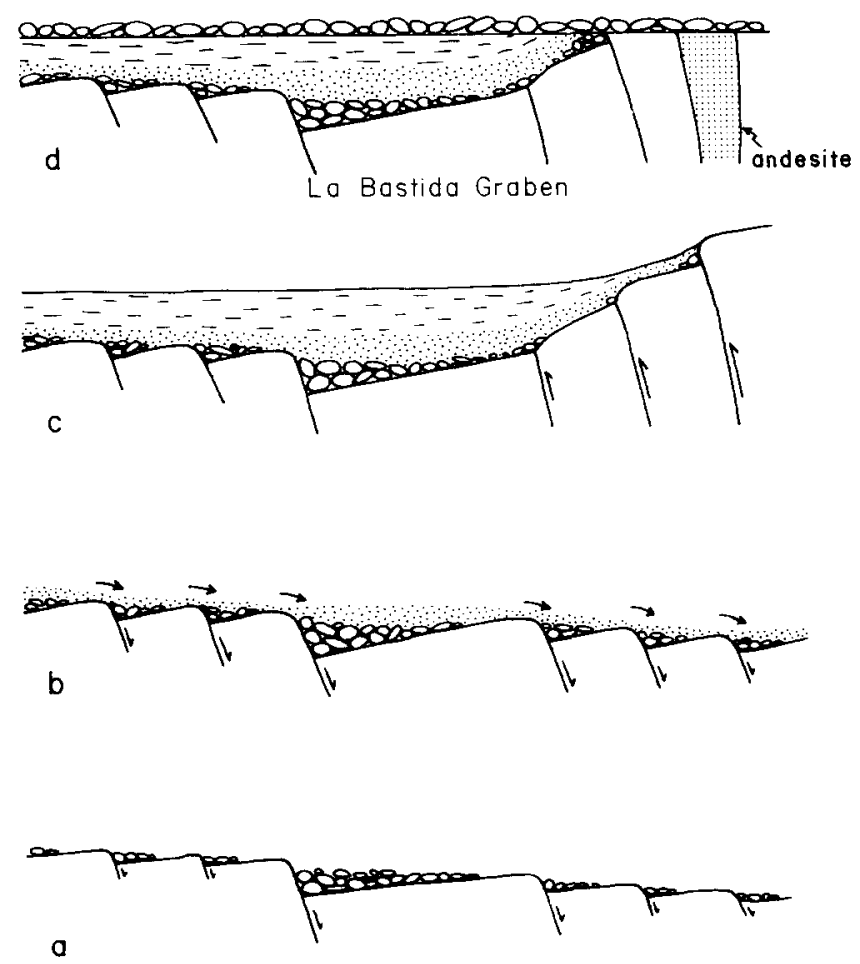

Fig. 23. Schematic strike section through the central part of the La Seu basin depicting normal faults perpendicular to the basin axis and westward tilted fault blocks. (a) Sedimentation restricted to N-S striking half-grabens (e.g. the La Bastida Graben). Paleocurrent directions run perpendicular to the section; (b) eastward transport of fine-grained sediments (compare Fig. 18); (c) during transpressional phases faults change character to reverse faults in the Ges Fault Zone; and (d) geometry after deformation and erosion. 
As discussed above, the traces of the east-west faults bounding the La Seu basin are well individualized and rather straight on a regional scale. This is a remarkable feature for a strike-slip zone in high crustal levels, as they often show a complicated anastomosing fault pattern dominated by Riedel shears (Harding, 1976; Tchalenko, 1970). Recent experiments have shown, however, that the development of fault configurations in a sedimentary cover as a response to faulting in a "basement" is dependent upon so-called pre-stress conditions. When the longest and shortest principal pre-stress axes are both horizontal, and parallel and perpendicular to the basement fault respectively, Riedel shears will only develop at low angles to this master fault (G. Mandl and M.A. Naylor, pers. commun., 1982). Furthermore, large displacements will cause the "breakthrough" of a master fault at the surface as Riedel shears and other associated structures become connected parallel to the basement fault (Tchalenko, 1970). With respect to the present study it is proposed that a tensile tectonic regime was responsible for graben development in Upper Carboniferous times, as witnessed by the outpouring of substantial amounts of tuff and lava. When the tectonic regime changed into one of oblique-slip faulting, tensile pre-stress conditions prevented Riedel shears from developing at high angles to the graben-axis direction. Subsequently, large displacements along the master fault straightened the basin boundary faults.

An additional speculation about the rather straight outline of the faults is to assume that they are reactivations of an older (Variscan or pre-Variscan?) fault system. Any stress field applied will cause slip along pre-existing planes of weakness as long as the angular relationships between principle stress axes and fault planes are favourable (Price, 1966; Jaeger, 1969).

\section{SUMMARY AND CONCLUSIONS}

(1) The La Seu basin is one of a series of east-west striking, narrow post-Variscan sedimentary basins, cropping out in a single, well-defined zone along the southern border of the Axial Zone of the Pyrenees (Mey et al., 1968; Brouwer, 1968; Bloemraad, 1969; Nagtegaal, 1969; Hartevelt, 1970; Gisbert, 1981). Some postVariscan basins further to the west show an evolution comparable to that of the La Seu basin, including eastward migration of their depocentre.

(2) The strong correlation between sequences, megasequences and basinfill sequences throughout the basin, proves that tectonic control was of major importance for its development. The absence of any trace of regional metamorphism in the post-Variscan rocks indicates that the deformation must have been of the shallowcrustal type.

(3) The overall net strike-slip/net dip-slip ratio within the basin is at least five, but probably more, whereas its length/width ratio is ten or more. 


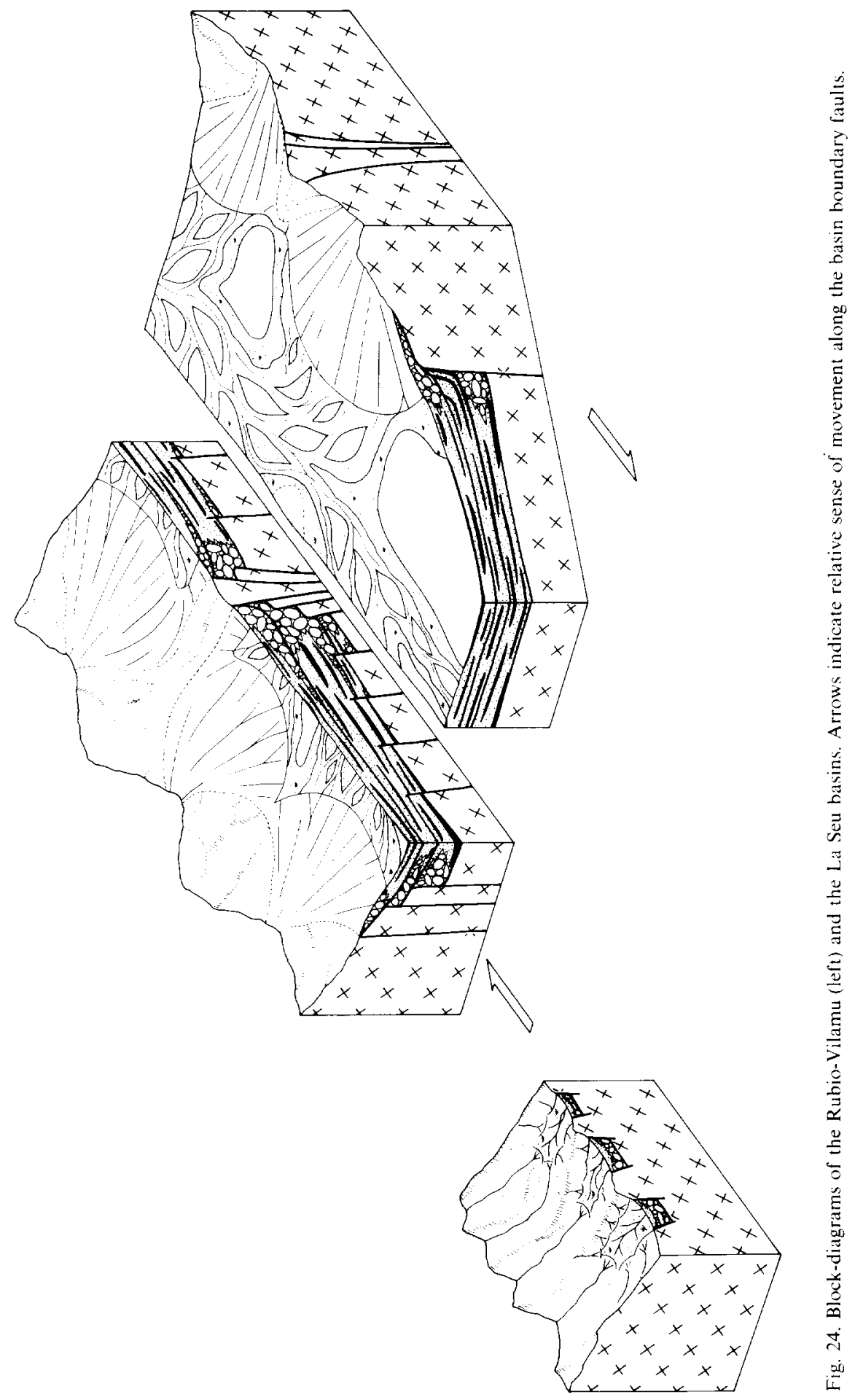


(4) Considerable shift of the depocentre occurred in space and time.

(5) Normal faulting, drape folding and outpouring of lavas point to (trans-)tensional tectonics, where the occurrence of erosional levels, angular unconformities and reverse faulting point to (trans-)pressional tectonics. Alternation of transtension and transpression is considered to be typical of strike-slip basins (Reading, 1980) and results from movement along non-planar fault surfaces.

(6) Tensional pre-stress conditions and graben development as indicated by the presence of extrusive rocks in the Upper Carboniferous, gave rise to the development of a set of straight and well-defined bounding faults. Alternatively, reactivation of older structures can certainly not be excluded.

(7) Throughout the evolution of the La Seu basin cross-cutting faults like the Ges Fault Zone repetitively changed character from normal to reverse faults.

(8) Several relatively small north-south running grabens, such as the RubioVilamu grabens, acted as lateral feeder channels to the La Seu basin, with basinward transport to the south as well as to the north. In the La Bastida Graben, paleocurrent directions can therefore be $180^{\circ}$ opposed within the same sedimentary unit.

(9) Due to the shape of the basin, transport of coarse debris was mainly lateral with tectonically induced deflections towards the east (i.e. the direction of depocentre migration), especially in the lower and upper fine-grained parts of megaand basinfill sequences.

(10) Alluvial fans and ephemeral streams coalesced to form bajadas, pointing to straight boundary faults, low gradients, smooth topography, and semi-arid climatic conditions.

(11) Important changes in pebble composition, types of megasequences and paleocurrent directions between Basinfill Sequences $A-E$ and $F$, are indicative of changes in tectonic regime: from a repetition of transtensile/transpressive tectonics to a major transtensile phase, with associated large-scale vertical movements.

The structural setting and geometry of the sediment fill of the Rubio-Vilamu and the La Seu basins are conceptually depicted in Fig. 24.

\section{ACKNOWLEDGEMENTS}

I am very much indebted to Dr. P.J.C. Nagtegaal who thoroughly reviewed several versions of this article, and to my former supervisors and colleagues at the Structural Geology Department of Utrecht State University where this work was initiated. In particular I thank Mr. W. Nijman for guidance in the field and his permanent assistance and enthusiasm. Bart van Hasselt and Eppo van Straten assisted during fieldwork.

Throughout every stage of this study Ineke Smeets was a continuous source of help and stimulation, for which I am very grateful. 


\section{REFERENCES}

Allen, P.A., 1981. Sediments and processes on a small stream-flow dominated Devonian alluvial fan, Shetland Islands. Sediment. Geol., 29: 31-66.

Ballance, P.F., 1980. Models of sediment distribution in non-marine and shallow marine environments in oblique-slip fault zones. In: P.F. Ballance and H.G. Reading (Editors), Sedimentation in Oblique-Slip Mobile Zones. Spec. Publ. Int. Assoc. Sediment., 4: 229-236.

Bixel, F. and Lucas, C., 1983. Magmatisme, tectonique et sédimentation dans les fossés stéphano-permiens des Pyrénées occidentales. Rev. Géogr. Phys. Géol. Dyn., 24: 329-342.

Blatt, H., Middleton, G.V. and Murray, R.C., 1972. Origin of Sedimentary Rocks. Prentice-Hall, Englewood Cliffs, N.J., 634 pp.

Bloemraad, J., 1969. Verslag van een geologische kartering tussen het Cerdaña bekken en Ribas de Freser. Intern Rep. Univ. Leiden, 44 pp.

Bluck, B.J., 1967. Deposition of some Upper Old Red Sandstone conglomerates in the Clyde area: A study in the significance of bedding. Scott. J. Geol., 3: 139-167.

Brookfield, M.E., 1980. Permian intermontane basin sedimentation in southern Scotland. Sediment. Geol., 27: 167-194.

Brouwer, Th.N., 1968. Verslag van een geologische kartering in de omgeving van de Cerdaña vallei, oostelijke Pyreneeèn, Spanje. Intern Rep. Univ. Leiden, 34 pp.

Collinson, J.D., 1978a. Deserts. In: H.G. Reading (Editor), Sedimentary Environments and Facies. Blackwell, London.

Collinson, J.D., 1978b. Alluvial sediments. In: H.G. Reading (Editor), Sedimentary Environments and Facies. Blackwell, London.

Deegan, C.E., 1973. Tectonic control of sedimentation at the margin of a Carboniferous depositional basin in Kirkudbrightshire. Scott. J. Geol., 9: 1-28.

Folk. R.L. and Ward. W.C., 1957. Brazos River Bar: a study in the significance of grain size parameters. J. Sediment. Petrol, 27: 3-27.

Gisbert, J., 1981. Estudio geológico-petrológico del Estefaniense-Pérmico de la Sierra del Cadí (Pirineo de Lérida). Tesis Doctoral, Departamento de Petrología, Universidad de Zaragoza, 313 pp.

Harbaugh, J.W. and Bonham-Carter, G., 1970. Computer Simulation in Geology. Wiley-Interscience. New York, N.Y., 575 pp.

Harding, T.P., 1976. Predicting productive trends related to wrench faults. World Oil, 182: 64-69.

Harland, W.B., 1971. Tectonic transpression in Caledonian Spitzbergen. Geol. Mag., 108: $27-42$.

Hartevelt, J.J.A., 1970. Geology of the upper Segre and Valira Valleys, Central Pyrenees, Andorra/Spain. Leidse Geol. Meded., 45: 167-236.

Hartevelt, J.J.A. and Roger, Ph., 1968. Quelques aspects de la topographie permo-triassique dans le Haute-Sègre et de la Haute-Pallaresa (Lérida. Espagne), C.R. Somm. Séances Soc. Géol. Fr., 6: $182-184$.

Heward, A.P., 1978a. Alluvial fan sequence and megasequence models: with examples from Westphalian D-Stephanian B coalfields, northern Spain. In: A.D. Miall (Editor), Fluvial Sedimentology. Mem. Can. Soc. Pet. Geol., 5: 669-702.

Heward, A.P., 1978b. Alluvial fan and lacustrine sediments from the Stephanian A and B (La Magdalena, Ciñera-Matallana and Sabero) coalfields, northern Spain. Sedimentology, 25: 451-488.

Jaeger, J.C., 1969. Elasticity, Fracture and Flow with Engineering and Geological Applications. Methuen, London, $268 \mathrm{pp}$.

Jones, B. and Dixon, O.A., 1976. Storm deposits in the Read Bay Formation (Upper Silurian), Somerset Island, Arctic Canada (An application of Markov Chain Analysis). J. Sediment. Petrol., 46: $393-401$.

McGowen, J.H. and Groat, C.G., 1971. VanHorn Sandstone, West Texas: an alluvial fan model for mineral exploration. Report of Investigations, No. 72, 57 pp. Bureau of Economic Geology, Univ. of Texas, Austin, Texas. 
Mey, P.H.W., 1968. Geology of the Upper Ribagorzana and Tor valleys, Central Pyrenees, Spain. Leidse Geol. Meded., 41: 229-292.

Mey, P.H.W., Nagtegaal, P.J.C., Roberti, K.J. and Hartevelt, J.J.A., 1968. Lithostratigraphic subdivision of post-Hercynian deposits in the South-Central Pyrenees, Spain. Leidse Geol. Meded., 41: 221-228.

Miall, A.D., 1973. Markov chain analysis applied to an ancient alluvial plane succession. Sedimentology, 20: $347-364$.

Miall, A.D., 1978. Tectonic setting and syndepositional deformation of molasse and other nonmarine-paralic sedimentary basins. Can. J. Earth Sci., 15: 1613-1632.

Morre, N. and Thiébaut, J., 1964. Constitution de quelques roches volcaniques permiennes de la Sierra del Cadi (Pyrénées catalanes). Bull. Soc. Géol. Fr., VI: 389-396.

Nagtegaal, P.J.C., 1969. Sedimentology, paleoclimatology, and diagenesis of post-Hercynian continental deposits in the south-central Pyrenees, Spain. Leidse Geol. Meded., 42: 143-238.

Price, N.J., 1966. Fault and Joint Development in Brittle and Semi-Brittle Rock. Pergamon Press, New York, N.Y., 176 pp.

Reading, H.G., 1980. Characteristics and recognition of strike-slip fault systems. In: P.F. Balllance and H.G. Reading (Editors), Sedimentation in Oblique-Slip Mobile Zones. Spec. Publ. Int. Assoc. Sedimentol., 4: 7-26.

Reading, H.G., 1978. Sedimentary Environments and Facies. Blackwell, Oxford, 557 pp.

Schumm, S.A., 1973. Geomorphic thresholds and complex response of drainage systems. In: M. Morisawa (Editor), Fluvial Geomorphology.( Publ. in Geomorphology) State University of New York, Binghampton, N.Y., pp. 299-310.

Séguret, M., 1970. Etude tectonique des nappes et séries décollées de la partie centrale du versant sud des Pyrénées. Ph.D. thesis, Montpellier, $155 \mathrm{pp}$.

Sopeña, A., Virgili, C., Hernando, S. and Ramos, A., 1977. Pérmico continental en España. Cuad. Geol. Iber., 4: 11-34.

Soula. J.-C., Lucas, C. and Bessière, G., 1979. Genesis and evolution of Permian and Triassic basins in the Pyrenees by regional simple shear acting on older Variscan structures: field evidence and experimental models. Tectonophysics, 58: T1-T9.

Steel, R.J., 1974. New Red Sandstone floodplain and piedmont sedimentation in the Hebridean Province. J. Sediment. Petrol., 44: 336-357.

Steel, R.J. and Gloppen, T.G., 1980. Late Caledonian (Devonian) basin formation, western Norway: signs of strike-slip tectonics during infilling. In: P.F. Ballance and H.G. Reading (Editors), Sedimentation in Oblique-Slip Mobile Zones. Spec. Publ. Int. Assoc. Sedimentol., 4: 79-103.

Steel, R.J. and Wilson, A.C., 1975. Sedimentation and tectonism (?Permo-Triassic) on the margin of the North Minch Basin, Lewis. J. Geol. Soc. Lond., 131; 183-202.

Tchalenko, J.S., 1970. Similarities between shear zones of different magnitudes. Bull. Geol. Soc. Am., 81 : $1625-1640$.

Zwart, H.J., 1979. The geology of the central Pyrenees. Leidse Geol. Meded., 50: 1-74.

Zwart, H.J. and Roberti, K.F., 1976. Geological map of the central Pyrenees. Sheet 9: Flamisell-Pallaresa. Geol. Inst., Leiden. 